\title{
Archaeology of the Brasada: A Cultural Resources Assessment of the Chevron Resources Company Properties in Northeastern Duval County, Texas
}

\author{
A. Joachim McGraw \\ Beverly J. Van Note \\ Courtenay J. Jones
}

Follow this and additional works at: https://scholarworks.sfasu.edu/ita

Part of the American Material Culture Commons, Archaeological Anthropology Commons, Environmental Studies Commons, Other American Studies Commons, Other Arts and Humanities Commons, Other History of Art, Architecture, and Archaeology Commons, and the United States History Commons

Tell us how this article helped you.

This Article is brought to you for free and open access by the Center for Regional Heritage Research at SFA ScholarWorks. It has been accepted for inclusion in Index of Texas Archaeology: Open Access Gray Literature from the Lone Star State by an authorized editor of SFA ScholarWorks. For more information, please contact cdsscholarworks@sfasu.edu. 


\section{Archaeology of the Brasada: A Cultural Resources Assessment of the Chevron Resources Company Properties in Northeastern Duval County, Texas}

\section{Creative Commons License}

\section{(c) (1) \&}

This work is licensed under a Creative Commons Attribution-NonCommercial 4.0 International License 


\section{ARCHAEOLOGY OF THE BRASADA: \\ A CULTURAL RESOURCES ASSESSMENT OF THE CHEVRON RESOURCES COMPANY PROPERTIES IN NORTHEASTERN DUVAL COUNTY, TEXAS}

A. Joachim McGraw, Beverly J. Van Note, and Courtenay J. Jones

Center for Archaeological Research The University of Texas at San Antonio ${ }^{-}$

Archaeological Survey Report, No. 113 



\begin{abstract}
Within the past decade, cultural resource management has become an increasingly significant aspect of archaeological investigations in southern Texas. Twenty-five new sites were identified, recorded, and assessed as the result of a 4000-acre cultural resources survey in northeastern Duval County, southern Texas, by the Center for Archaeological Research, The University of Texas at San Antonio, from October to December 1981. The investigations were carried out under the requirements and guidelines of the National Historic Preservation Act of 1966, as amended, the Vernon Texas Civil Statute 4590f, as amended, and the Guidelines for Archeological Investigations of Mining Areas in Texas (Texas Historical Commission 1981).
\end{abstract}




\section{TABLE OF CONTENTS}

ABSTRACT

LIST OF TABLES . . . . . . . . . . . . . . . . . . . . . . . . . . . . . . . . . . . . . . ii i

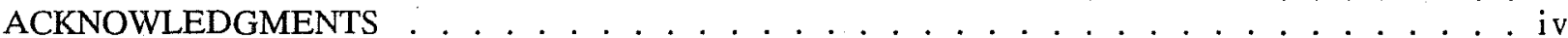

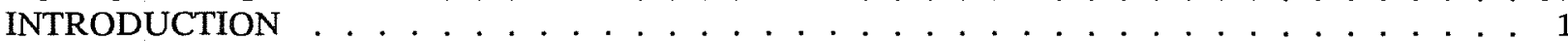

ENVIRONMENTAL BACKGROUND . . . . . . . . . . . . . . . . . . . . . . . 1

Physiographic Environment . . . . . . . . . . . . . . . . . . . 3

Biotic Resources . . . . . . . . . . . . . . . . . . . . . . . . . . . . . . . . 3

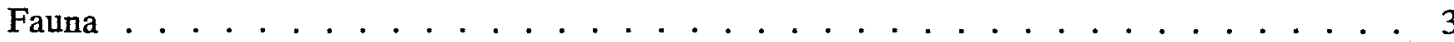

Flora . . . . . . . . . . . . . . . . . . . . . 4

ARCHAEOLOGICAL BACKGROUND . . . . . . . . . . . . . . . . . . . . . . . . 5

Previous Research . . . . . . . . . . . . . . . . . . . . . . . 6

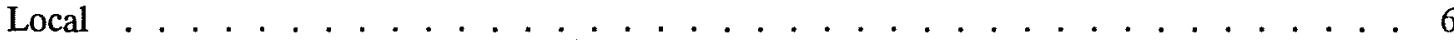

Regional .......................... 6

Prehistoric Background . . . . . . . . . . . . . . . . . . . . . . . . 7

Paleo-Indian Period . . . . . . . . . . . . . . . . . . . . . . . . . . . . . . 8

Archaic Period . . . . . . . . . . . . . . . . . . . . . . . . . . . . . 8

Late Prehistoric Period ． . . . . . . . . . . . . . . . . . . . . . . . . . . . . . 9

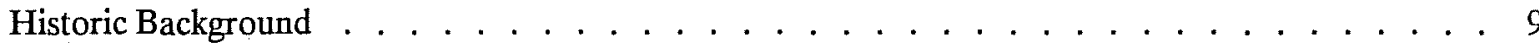

Historic Indian Groups . . . . . . . . . . . . . . . . . . . . . . . . . . . . . . . 9

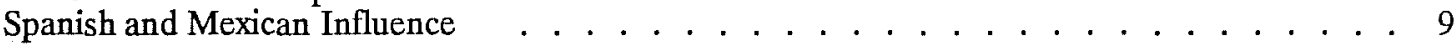

Ranching and Rustling . . . . . . . . . . . . . . . . . . . . . . . . . . . . . . 10

Organization of Duval County . . . . . . . . . . . . . . . . . . . . . . . . . . . . 10

RESEARCH DESIGN . . . . . . . . . . . . . . . . . . . . . . . . . . . 11

SITE DESCRIPTIONS . . . . . . . . . . . . . . . . . . . . . . . . . . . 13

Site 41 DV $17 \ldots \ldots \ldots \ldots$

Site 41 DV 18 . . . . . . . . . . . . . . . . . . . . . . . . . . . . . . . . . . 14

Site 41 DV $19 \ldots \ldots \ldots \ldots$

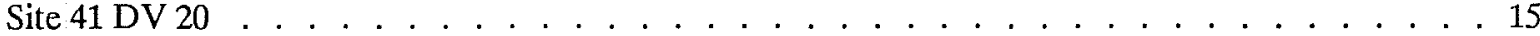

Site 41 DV $21 \ldots \ldots \ldots \ldots$

Site 41 DV 22 . . . . . . . . . . . . . . . . . . . . . . . . . . . . . . . . . . . . 15

Site 41 DV $23 \ldots \ldots \ldots \ldots$

Site 41 DV $24 \ldots \ldots$. . . . . . . . . . . . . . . . . . . . . . . . . 17

Site 41 DV 25 . . . . . . . . . . . . . . . . . . . . . . . . . . . . . . . . . 17

Sites 41 DV 26 and 41 DV 27 . . . . . . . . . . . . . . . . . . . . . . . . . . . . . . . . . . . . . . . . 17

Site 41 DV $28 \ldots \ldots \ldots \ldots$

Site 41 DV 29 . . . . . . . . . . . . . . . . . . . . . . . . . . . . . 18

Site 41 DV $30 \ldots \ldots$. . . . . . . . . . . . . . . . . . . . . . 19

Site 41 DV 31 . . . . . . . . . . . . . . . . . . . . . . . . . . . . 19

Site 41 DV $32 \ldots \ldots$. . . . . . . . . . . . . . . . . . . . . . . . . 19

Site 41 DV 33 . . . . . . . . . . . . . . . . . . . . . . . . . . . . . . . 20

Site 41 DV $34 \ldots \ldots \ldots$

Site 41 DV 35 . . . . . . . . . . . . . . . . . . . . . . . . . . . . 21

Site 41 DV 36 . . . . . . . . . . . . . . . . . . . . . . . . 21

Site 41 DV 37 . . . . . . . . . . . . . . . . . . . . . . . . . . . . . . 21

Site 41 DV $38 \ldots \ldots$. . . . . . . . . . . . . . . . . . . . . . . . . . . . 22

Site 41 DV 39 . . . . . . . . . . . . . . . . . . . . . . . . . . . . . . . . . . . . . 22

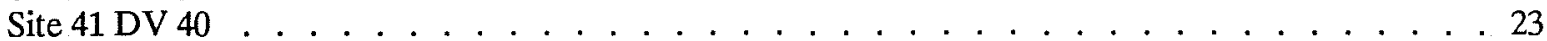

Site 41 DV 41 . . . . . . . . . . . . . . . . . . . . . . . . . . . . . . . 23

CULTURAL MATERIALS ANALYSIS . . . . . . . . . . . . . . . . . . . . . . . . . . . 24

Prehistoric Materials . . . . . . . . . . . . . . . . . . . . . . . . . . . . . . . . . . 24

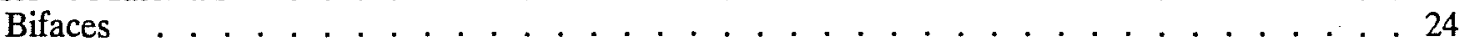

Unifaces . . . . . . . . . . . . . . . . . . . . . . 28

Ground Stone . . . . . . . . . . . . . . . . . . . . . . . . . . . . . . . . . 28

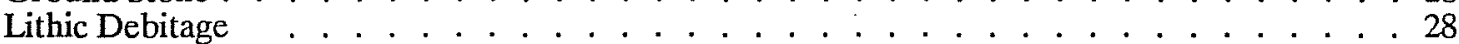

Historic Materials _. . . . . . . . . . . . . . . . . . . . . . . . . . . . . . . . . . . . . 29

Glassware . . . . . . . . . . . . . . . . . . . . . . . . . 29

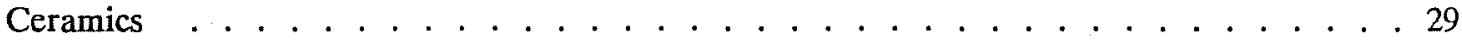


Automotive Accessories . . . . . . . . . . . . . . . . . . 31

Firearm Accessories . . . . . . . . . . . . . . . . . . . . . . . . . . . . . . . . . . . . . 31

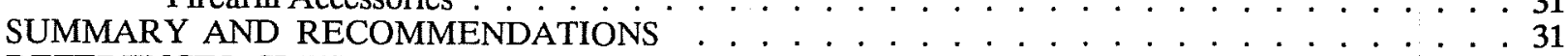

REFERENCES CITED . . . . . . . . . . . . . . . . . . . . . . . . . . . . . . . . . . 35

APPENDIX: DEFINITIONS OF LITHIC TERMS . . . . . . . . . . . . . . . . . . . . . . . . . 41

\section{LIST OF FIGURES}

1. Location of Archaeological Sites in Study Area . . . . . . . . . . . . . . . . . . . . . . . . 2

2. Land Ownership in the Study Area . . . . . . . . . . . . . . . . . . . . . . . . . . . . . 12

3. Selected Artifacts from the Duval County Survey . . . . . . . . . . . . . . . . . . . . . . . 27

\section{LIST OF TABLES}

1. Distribution of Collected Cultural Materials . . . . . . . . . . . . . . . . . . . . . . 25

2. Description of Lithic Artifacts . . . . . . . . . . . . . . . . . . . . . . . . . . . . . . . . . . . . . . . . . . 26

3. Inventory of Historic Materials . . . . . . . . . . . . . . . . . . . . . . . . . . 30

4. Elevations and Overview Directions of Archaeological Sites . . . . . . . . . . . . . . . . 33

5. Recommendations . . . . . . . . . . . . . . . . . . . . . . . . 34 


\section{ACKNOWLEDGMENTS}

The authors thank all those whose cooperation and expertise contributed to the successful completion of this report. Many personnel from the Chevron Resources Company were extremely helpful and cooperative during all phases of the survey operations and report preparation, especially Lonnie Tracy, project geologist. Dr. Thomas R. Hester, director, and Jack Eaton, associate director, of the Center for Archaeological Research, provided both guidance and expertise. Mary Lou Ellis, Carol Graves, Pat Wallace, Mary Lehr, and Sharon Quirk of the Center staff were instrumental in the completion of this report. Personnel from the Texas Land Office, Austin, and Carolyn Spock of the Texas Archeological Research Laboratory, Austin, were extremely cooperative during background research. 


\section{INTRODUCTION}

A cultural resources survey of 4000 acres in northeastern Duval County was conducted by archaeologists from the Center for Archaeological Research (CAR), The University of Texas at San Antonio (UTSA), from October through early December 1981. Following a contract, Service Order S87178 dated August 31, 1981, between Mr. Lonnie Tracy of the Chevron Resources Company and Dr. Thomas $R$. Hester, CAR director, personnel from the CAR began archaeological investigations of five adjoining properties north of State Highway 44, approximately half way between the town of Freer and the county seat of San Diego.

The field survey was conducted by A. Joachim McGraw and Daniel Potter, research associates, and Courtenay Jones, technical staff assistant, of the CAR. Dr. Thomas R. Hester, director, and Jack D. Eaton, associate director, provided general supervision of the project. All work was conducted as per the requirements of the National Historic Preservation Act of 1966, as amended, and the Vernon Texas Civil Statute 4590f, as amended. Considerations were also given to the Guidelines for Archeological Investigations of Mining Areas in Texas (Texas Historical Commission 1981) as these Chevron-leased properties were to be extensively modified by proposed mining operations.

The purpose of the survey work was threefold: (1) to identify and record all archaeological resources (historic and prehistoric) within the project area; (2) to assess the cultural significance of these resources; and (3) to make recommendations for further action as necessary should these resources be significant.

The investigated area was characterized by vast upland expanses of chest-high (or higher), often extremely dense, thorny brush on rolling hills. No permanent water courses were located in the study area, although dry Los Ineinitos (may be misspelled, illegible at the Texas Land Office) Creek and several ephemeral tributaries bisected the lower portions of the survey properties. A large portion of the study area was gridded by a series of mostly parallel senderos often as close as 25 to $50 \mathrm{~m}$. Originally cleared by personnel and equipment from the Chevron Resources Company, these senderos were quickly exploited by the archaeological survey crew. The senderos, when available, provided a systematic means of ground coverage through what otherwise would have been almost impenetrable brush.

Based on the goals previously stated, four specific survey methods were employed during operations: (1) the entire project area was surveyed by a series of systematic transects; (2) the surface extent of all cultural resources was determined and plotted on USGS 1:24,000 scale topographic maps; (3) limited surface collections and spot shovel tests were made when necessary to further evaluate site descriptions; and (4) preliminary archival research was initiated to identify potential historic resources as well as to determine the historical background of the project area. Research methodology followed the guidelines presented in Hester, Heizer, and Graham's Field Methods in Archaeology (1975) and the Council of Texas Archeologists' (1981:I-III) guidelines. Field operations consisted of a series of systematic transects (employing senderos whenever possible) with a primary emphasis on the collection of diagnostic or otherwise significant artifacts. Site elevations as well as distances from water sources (intermittent) in the study location were recorded.

Twenty-five sites were identified, recorded, and assessed during the course of the survey. These sites are plotted in Figure 1. Data from all identified sites were recorded on standard site survey forms used by the Center; these survey forms, all collected materials, and additional records are curated and permanently housed at the CAR-UTSA. A brief summary of general site characteristics as well as related background information and recommendations for further work are presented in the following pages.

\section{ENVIRONMENTAL BACKGROUND}

Duval County lies in the gently rolling uplands marginal to the south Texas Coastal Plain. An early Texas emigrant once described this vast area between the Nueces River and the Rio Grande as "miserably poor" (Stiff 1968:26) and "badly supplied with water" (ibid.:25). Today, however, the dry brush country of Duval County supports its inhabitants through oil and gas production, largescale ranching and farming, and the production of brine for use by chemical industries in other 
This page has been

redacted because it

contains restricted

information. 
areas of the state (Shafer 1974:4). An examination of the physiographic environment and biotic resources of the county is helpful in providing an adequate assessment of the archaeological sites identified in the area.

\section{PHYSIOGRAPHIC ENVIRONMENT}

Blair (1950), who includes this portion of south Texas in the Tamaulipan Biotic Province, describes the area's climate as semiarid and megathermal, noting a marked deficiency of moisture available for plant growth. According to local records from 1917 to 1979, rainfall for Duval County averages 24.1 inches per year (Soil Conservation Service 1980). September receives the highest rainfall with an average of 3.46 inches, while the annual rainfall for May and June is 2.70 and 2.68 inches, respectively (ibid.). Precipitation is lightest during the winter months. In spite of small amounts of moisture, a mild average temperature of $72^{\circ} \mathrm{F}$ provides a growing season of 289 days. Winds are generally from the south and southeast.

In The Natural Regions of Texas, Johnson (1931) characterizes the locality as one of "erosional topography." He describes it as an upland belt of mixed grasses and chaparral largely underlain by indurated caliche and containing ridges of boulder deposits often accompanied by thick caliche deposits (ibid.:139).

The Goliad Sand, which outcrops in more than half of Duval County, is the major geologic formation in the survey area. This Pliocene formation contains fine to coarse calcareous sand, mostly gray in color, interbedded with sandstone, gravel, and variously colored calcareous clays. It ranges in thickness from 0-600 feet, and dips east to southeast at about 35 to 45 feet per mile (Shafer 1974). This formation is overlain in southeastern portions of the county by the Pleistocene Lissie Formation and later aeolian deposits. The Goliad Sand almost entirely overlaps the Upper Miocene Fleming Formation; the even earlier Oakville Sandstone outcrops only in north-central Duval County. Older geologic formations which underlie the Goliad Sand include the Lower Miocene Catahoula Tuff, the Frio Clay of the Oligocene, and an Eocene shale, sandstone, and a volcanic ash unit called the Jackson Group (ibid.). The Goliad Sand contains large amounts of caliche which in some places form a "cap rock" (Shafer 1974:8) over the formation. This geologic unit was previously identified as Lagarto or Upper Lagarto by some geologists, and the associated caliche deposits were termed the "Reynosa caliche" (Weeks 1933:467).

The soils which overlie the Goliad Sand in the survey area are of the Randado-Cuevitas-Olmos association. Randado soils are composed of a very friable, slightly acidic, reddish brown fine sandy loam. Cuevitas soils have a very friable, neutral brown or reddish brown fine sandy loam composition, while Olmos soils are a friable, moderately alkaline, grayish brown gravelly loam. All three types overlie various types of pinkish white to white cemented caliche, and are only moderately deep to shallow. These soil types are well drained and have moderately permeable lower layers (U.S. Department of Agriculture 1981).

There are no permanent streams in Duval County; the only available supply of surface water is storm runoff (Soil Conservation Service 1980). Only a small amount of precipitation penetrates the soil and subsoil to become part of the water table. The Goliad Sand Formation is the principal aquifer in the county, and wells tapping it yield varying amounts of fresh to slightly saline water (Shafer 1974:24).

\section{BIOTIC RESOURCES}

\section{Fauna}

Faunal resources in the survey area are quite diverse. Blair (1950) states that 61 mammal, 36 snake, 19 lizard, two land turtle, three urodele, and 19 anuran species occur in association with the Tamaulipan fauna of the area. This combination includes several Neotropical species, some grassland species from the Texan and Kansan provinces, and still other species from the Austroriparian and Chihuahuan provinces (ibid.). 
According to Blair (1950), Mexican ground squirrels, hispid pocket mice, Merriam pocket mice, northern grasshopper mice, white-footed mice, hispid cotton rats, southern plains wood rats, and eastern cottontail rabbits make up the bulk of the small mammal population. The eastern mole, Ord kangaroo rat, Texas pocket gopher, several species of skunk, and jackrabbit are also common (ibid.:104; Burt and Grossenheider 1964). Larger mammals include peccary (Tayassu angulatum), armadillo (Dasypus novemcinctus), white-tailed deer (Odocoileus virginianus), coyote (Canis latrans), ocelot (Felis pardalis), and puma (Felis concolor) (Blair 1950; Burt and Grossenheider 1964; Bailey 1971). Red wolf (Canis niger) may have been present in recent times (Burt and Grossenheider 1964). Blair (1950:104) also mentions the jaguar (Felis onca) among species known from the area in recent times. Bison (Bison bison) have been documented as part of the area's past faunal assemblage in nearby Jim Wells County (Hester 1977), and mustangs are reported to have been numerous in the area in the late 18th century (Sibley 1967). Wild cattle and burros were also common in the area in historic times; the King Ranch did not succeed in clearing its range of wild burros until the early 1920s (Dobie 1929:42). Antelope are frequently mentioned in historic reports (Inglis 1964).

Common lizard species include the Texas banded gecko, Texas spiny lizard, eastern fence lizard, Texas spotted whiptail, and the Texas horned lizard (Blair 1950; Zim and Smith 1956; Stebbins 1966). One early traveler to Texas said of the unusual horned lizard: "The thing looks very fierce, and at first sight reminded me, very forcibly, of the representation of the Dragon in the Bible, only that it was deficient in wings" (Sibley 1967:168).

Snakes most common in the area include the coachwhip, glossy snake, plain-bellied water snake, diamond-backed water snake, checkered garter, ribbon garter; indigo snake, and the western diamondback rattlesnake. In addition, several species of toads, cricket frogs, chorus frogs, and bullfrogs occur frequently (Blair 1950; Zim and Smith 1956; Stebbins 1966).

Numerous bird species are also present, as Texas boasts the largest avifauna (over 540 species recorded) of any of the 50 states (Peterson 1963). Among the many present in the survey area are wild turkey, herons, cranes, ducks, geese, quail, prairie chicken, and numerous hawk species (ibid.; Inglis 1964).

\section{Flora}

As is characteristic of the Tamaulipan Biotic Province, thorny brush is the predominant flora of the area. Most common are mesquite (Prosopis juliflora), several species of Acacia and Mimosa, granjeno (Celtis pallida), guayacan (Porlieria angustifolia), ceniza (Leucophyllum texana), whitebrush (Aloysia texana), prickly pear (Opuntia lindheimeri), tasajillo (Opuntia leptocaulis), and Condalia and Castela species (Blair 1950:103). Jones (1977) describes a chaparral growth of guajillo, blackbrush, ceniza, tanglewood, bee-bush, mescalbean, desert yaupon, guayacan, joint fir, colima, granjeno, agarito, lotebush, goatbush, Texas ebony, mesquite, and prickly pear that is particularly associated with outcrops of Reynosa caliche.

Several species of bluestem grasses, as well as buffalograss (Buchloe dactyloides), curly mesquite (Hilaria belangeri), and species of bristlegrass (Pappophorum), rhodesgrass (Chloris), and grama (Bouteloua) are also present, although somewhat less common, in the area (Gould 1975). In addition, buffelgrass (Cenchrus ciliarus) has recently become abundant (ibid.:4).

Records of early travelers, however, reveal that the area was not characteristically so brushy before the arrival of the Spanish (Sibley 1967:52). Jones (1977) in his analysis of Coastal Bend flora suggests that the area was then a prairie grassland with an abundance of annual and perennial nongrassy herbs and only scattered mesquite and prickly pear. Ash, elm, box elder, willow, retama, and buisache occurred along drainages. Hackberry, chittimwood, anaqua, black persimmon, soapberry, live oak, and mesquite also occurred on the uplands. In 1833, when Benjamin Lundy crossed Duval County on a trip from Laredo to San Patricio, he commented on the abundance of thick grass in southern portions of the county and described the area in the vicinity of San Diego as a "plain" (Inglis 1964:29-30).

By the late 1800 s, however, brushy growth was beginning to choke the lands between the Nueces River and the Rio Grande. When Havard crossed Duval County by train in 1885, he noted that the 
southwestern corner of the county was an open grassy plain, but that shrubbery "became denser and larger" as he traveled from present-day Benavides to San Diego (ibid.:30). Gould (1975) names specifically an increase in mesquite, live oak (Quercus virginiana), post oak (Quercus stellata), and Opuntia and Acacia species. This chaparral growth is usually attributed to overgrazing by livestock and a decrease in the prairie fires which had previously swept the countryside about once a year (Johnson 1931:137). According to one vaquero's account, McMullen, Webb, Duval, and Live Oak Counties contained "the worst brush in the United States of America" (Dobie 1929:201). This thicket of thorny plants became known as the "Brasada" (ibid.)*. One trail driver told of herding 3200 longhorn steers through the brasada. The trip began at Peña Station (Hebbronville), just south of the Duval County line, and continued through western Duval County to Black Water Creek in southeastern La Salle County with no water to be found along the entire route. The driver's description of that trip still seems accurate today: "All that saved the cattle on this dry drive was prickly pear, which has considerable moisture in its leaves. At that time there was no grass at all in that country. Nothing but rattlesnakes and chaparral" (Dobie 1929:213).

Prickly pear may have been an important natural resource in the area even before its spread in the 19th century. Campbell and Campbell (1981) report that information from 1860 interviews recall a concentration of prickly pear cactus in Duval and Jim Wells Counties between San Diego and Alice. This resource may have been important to historic Indian groups such as the Mariames described by Cabeza de Vaca, who traveled southward from their Guadalupe River encampments during the summer months to harvest the prickly pear fruits (ibid.:14).

Mesquite may also have been an important early resource. Mesquite pods have been identified as a food gathered by preceramic cultures of the Southern Mexican Highlands as well as among peoples of the American Southwest (Flannery 1968:72). Bryant's (1974:415) studies have revealed that mesquite was also used as a dietary supplement in southwest Texas. Numerous other uses of mesquite have been recorded among cultures of the southwestern United States. In addition to its use as a food source, mesquite was important as a preferred fuel and as a raw material for making structures, weapons, tools, and fibers. It was often used for medicinal or cosmetic purposes, and its sap and bark were used in pigments for decorating pottery (Felger 1977). Whether mesquite had such a variety of uses in south Texas; or if it was even present, is speculative, but its probability as a source of food and fuel is quite likely even before its well-documented spread.

In summary, the unique and sometimes harsh environmental conditions of the study area have affected prehistoric adaptive strategies as well as more recent historical developments. The archaeology of the brasada, or brush country, reflects both aboriginal as well as modern attempts to exploit the varied natural resources of this area.

\section{ARCHAEOLOGICAL BACKGROUND}

The area surveyed lies within the archaeological region defined by Hester (1981) as south Texas. Although the archaeological record of the south Texas region is not yet fully understood, extensive excavations in recent years have added a great deal to our knowledge of its past. A summary of previous research in south Texas and a brief description of its prehistoric and historic background are presented. Additional information on the archaeology of southern Texas can be found in reports by Hester (1980) and Mallouf, Baskin, and Killen (1977). Detailed descriptions of projectile point and ceramic types can be found in Suhm and Jelks (1962).

\footnotetext{
*According to Dr. Gilberto Hinojosa, Division of Behavioral and Cultural Sciences, UTSA, and Dr. Sally E. Said, Division of Foreign Languages, UTSA (personal communication), "Brasada" is apparently a colloquial term. The word may be derived from the Spanish "brasa" meaning "red-hot coal" (Ramondino 1968:92) or possibly from "braza" which refers to a length of measurement, "fathom" (ibid.:93), and may refer to either burnings of the brush for land clearing purposes or the extent of brush cover. Dobie (1929:201) defines the term simply as "brush country."
} 


\section{PREVIOUS RESEARCH}

Local

At present, little is known about the archaeology of the interior coastal plain where Duval County is located. In fact, prior to this study, only 16 archaeological sites had been recorded in the entire county.

Hester (1971) described the surface collections of three prehistoric sites (41 DV 1, 41 DV 2, and 41 DV 3) in southeastern Duval County. Site 41 DV 1, which lies in the Los Olmos Creek floodplain, had the heaviest concentration of artifacts and may represent a preferred campsite. Site 41 DV 2 lies adjacent to Macho Creek, and 41 DV 3 is situated on a hill about one mile from any reliable water source. Both sites, although containing less cultural debris than 41 DV 1 , had a variety of tools.

The tool forms found at all three of these sites resemble previously reported types from other parts of southern Texas, with the exception of a series of small bifacial tools (ibid.:58). One possible Paleo-Indian dart point similar to the Golondrina was identified. A variety of dart points generally linked to the Archaic of the region was reported, including (in order of abundance) Catán, Matamoros, Desmuke, and Tortugas. The Late Prehistoric period is represented by Perdiz, Scallorn, and Toyah, as well as triangular and side-notched arrow points. Ceramics found at 41 DV 2 are comparable to Leon Plain and Goliad wares (Hester 1971). The presence of Olmos bifaces at these sites may link the area to coastal sites in Kleberg County where this tool form has also been found (ibid.).

Another Duval County site, $41 \mathrm{DV} 4$, is located near the Palangana salt dome basin, just northwest of the sites previously described. R. M. and Nancy Bowen (notes on file, Texas Archeological Research Laboratory, Austin) collected Desmuke, Matamoros, Refugio, and Lerma dart points, Fresno, Perdiz, and Scallom arrow points, and bifacial and unifacial tools.

Three additional prehistoric sites (41 DV 5, 41 DV 6, and 41 DV 7) have been recorded in northeastern Duval County in the vicinity of Ygnacio Creek (notes on file, Center for Archaeological Research, UTSA). All are eroded and show no indication of subsurface deposits. Several leafshaped dart points, one arrow point similar to Scallorn, several biface and uniface fragments, and a few bone-tempered plainware ceramic sherds are reported.

Site $41 \mathrm{DV} 8$ is an upland site located in the southwestern portion of the county in the vicinity of Mesquite Creek. Lithic debris and Clear Fork gouges are reported from this site by Prewitt and Nance (1980).

The remaining eight previously recorded sites are located in close proximity to $41 \mathrm{DV} 8$ and are described by Prewitt and Nance (1980). One of these sites (41 DV 16) is historic in age and is reported to contain the remains of a limekiln. Five of the prehistoric sites are upland in nature; the remaining two are located on terraces adjacent to Mesquite Creek. Artifacts reported include two dart points, apparently of the Matamoros type, one gouge, and a number of bifacial and unifacial tools, as well as cores and other lithic debris. One site may contain a disrupted hearth (Prewitt and Nance 1980:17).

\section{Regional}

Considerably more archaeological evidence is available for other areas of south Texas. Early research in the region was conducted by Anderson (1932) in the Rio Grande delta and MacNeish (1947) in far southern Texas and northern Mexico. Early regional comparisons are also presented by Jackson (1940), Campbell (1947), and Kelley (1947).

The first major project in south Texas involving a systematic design of survey, testing, and excavation was completed at Falcon Reservoir in Zapata and Starr Counties (Hartle and Stephenson 1951; Cason 1952; Jelks 1952, 1953). Gougelike tools and triangular projectile point forms were uncovered from deeply buried deposits of the Rio Grande terrace system. Suhm, Krieger, and Jelks (1954:124-143) proposed the Falcón and Mier foci for the Archaic period of the area. 
Characteristics of the Falcón focus were open campsites; Tortugas, Abasolo, and Refugio dart points; fist axes; triangular and leaf-shaped knives; gouges; and heavy side scrapers. The Mier focus was viewed as a continuation of the Falcón with the addition of Matamoros, Catán, Fresno, and Perdiz points. Not until Nunley (1971) re-evaluated the Archaic in this area of Texas did it become apparent that the prehistoric cultural entity was more diversified.

Early syntheses did not recognize any distinct Late Prehistoric manifestations in the interior of southern Texas; it was believed that the ancestors of the historic Coahuilteco groups survived in an Archaic life style until European contact (Hester and Hill 1975). But during the late 1960s and early 1970s, numerous articles documenting a variety of point types and tool forms, as well as bone tools, ceramics, and evidence of differing burial practices, helped to better define the archaeology of the region (Hester 1969a, 1969b, 1975a; Hester and Hill 1971a, 1975; Hester and Parker 1970; Hester and Shafer 1975). It was recognized that projectile points north of Dimmit and $\mathrm{La}$ Salle Counties are predominantly stemmed varieties, while farther south they are more often stemless (Nunley and Hester 1966; Hester, White, and White 1969). Hester (1975b) suggested that the south Texas chronology generally reflected the central Texas sequence, but with localized development of tool types. He also defined two primary cultural adaptations for the area: the maritime and savannah adaptations (Hester 1976). More recent research has been reported by Hester (1977, 1981), Lynn, Fox, and O'Malley (1977), and Story (1980).

\section{PREHISTORIC BACKGROUND}

As mentioned previously, Hester $(1976,1981)$ has described two cultural adaptations for southern Texas during the prehistoric cultural periods. While these adaptations are more strongly reflected in the remains of Late Prehistoric sites, a long period of a hunting and gathering subsistence during the Archaic suggests these adaptations extended to earlier populations as they adjusted to the available natural resources. A maritime adaptation is thought to have occurred along the southern Texas coast where prehistoric peoples generally subsisted on the resources associated with the bays, lagoons, and coastal beaches. Some utilization of nearby marginal inlands may have infrequently contributed to subsistence collections.

A savanna adaptation is postulated (Hester 1981) for aboriginal groups inhabiting areas farther inland and away from the Gulf coast. The seasonal availability of natural resources in inland areas, combined with the considerable diversity and broadly distributed archaeological remains across southern Texas, suggests prehistoric peoples may have been by necessity, more mobile to exploit these resources. Hester (ibid.) postulates localized adaptations to natural resources would have created high and low resource density areas that would have influenced the extent and density of occupations. Thus, an emphasis on seasonal exploitations of natural resources across broadly varying local environmental systems is thought to be a primary motivating factor for the mobility and the territorial range of aboriginal groups across southern Texas.

Floodplain or marginal floodplains are thought to have been the preferred occupation locations for prehistoric campsites that served as primary base camps for hunting and foraging into terraces and upland areas. The savanna subsistence pattern was probably dominated by a wide variety of plant foods as well as the exploitation of such fauna as white-tailed deer and smaller species, including rabbits, rodents, turkey, and even snails. There is no evidence that bison, thought to be in the region only infrequently, perhaps cyclically, played a major role in subsistence patterns or strategies. Ethnographic accounts from various early sources (as noted in Campbell and Campbell 1981) indicate that plant foods predominated subsistence collections throughout most of the annual hunting and gathering cycle for early historic Indian groups of the region.

Several comments may be added to Hester's (1981) observations. If such prehistoric adaptive strategies did occur throughout a large portion of southern Texas in the past and if the ethnographic descriptions of early historic Indian groups (e.g., Campbell and Campbell 1981) may be used to infer earlier subsistence patterns, several inferences can be noted. The maritime adaptive strategy might more accurately be referred to as a littoral subsistence pattern while the inland savanna pattern may (less succinctly) actually indicate a seminomadic, bilobate (transphysiographic) riparian/savanna adaptation. This refers to subsistence/occupation patterns centered around but not limited to the riparian zones of large drainages and their major 
tributaries. Postulated group territories are thought to have cross-cut distinct seasonal resource areas and physiographic boundaries. The mobility to exploit these high and low resource density areas, as identified by Hester (1981), is directly linked to these transphysiographic movements. The effect of migrating fauna such as bison or antelope across the interior must also be considered, as such potential food sources would qualitatively affect the intensity and density of local resources and their exploitation.

It is quite significant to note that the area of present-day Duval County played an important role in the annual subsistence pattern of early historic Indian groups of the region. As noted by the 16th-century explorer Cabeza de Vaca (discussed in some detail by Campbell and Campbell 1981:7-39), the prickly pear tuna fields of southern Texas, thought to be concentrated in western Nueces County and eastern Duval County, were an attractive and major food source for Indian groups who were usually found along the Colorado River and Guadalupe River drainages approximately 85-100 miles away (Campbell 1975; Campbell and Campbell 1981). Annual migrations to the prickly pear fields occurred in the summer through the fall.

The prehistoric chronology for this area follows the periods described by Hester (1980) and Story (1980): Paleo-Indian, Archaic, and Late Prehistoric. A brief summary of each period is presented.

Paleo-Indian Period (approximately 9000-6000 B.C.)

Paleo-Indian sites throughout southern Texas are generally characterized by a paucity of cultural remains in often eroded and disturbed contexts. Several localities suggest enigmatic evidences of activities that predate the well-established Clovis complex (ca. 11,000 years ago) but no conclusive data exist to date.

Two early Paleo-Indian traditions are indicated across the region during the time of a late/transitional environmental change from the Pleistocene Epoch to the gradual shift to the more modern climatic episodes. A North American Plains-related tradition is represented by the scattered remains of Clovis (ca. 9200 B.C.) and Folsom (ca. 8800-8500 B.C.) fluted projectile points and their accompanying lithic assemblages. As early as 8600 B.C., there is some evidence of a contemporary but distinct cultural tradition identified by Epstein, Hester, and Graves (1980:81-92) as the Small Projectile Point tradition partially characterized by small, unstemmed, triangular projectile points and/or bifaces with a distribution from northeastern Mexico through southern Texas. Both Paleo-Indian traditions are thought to have been regionally adapted to the distinctive natural resources available in southern Texas.

Late Paleo-Indian remains in the region are reflected by a variety of parallel-flaked, nonfluted projectile points and other lithic materials. Characteristic projectile points include Plainview, Golondrina, Angostura, Meserve, Milnesand, Lerma, and Scottsbluff (Weir 1956; Hester 1968, 1969a; Hester and Hill 1971b). Distally beveled stone tools known as Clear Fork may have also originated at this time (Hester 1976).

Archaic Period (approximately 6000 B.C.-A.D. 1000 or later)

A poorly defined cultural and environmental transition is thought to have occurred at the end of the Paleo-Indian period across the region, directly linked to changing climatic conditions. While the actual conditions of the changes are not fully understood, the far-ranging effects of these environmental influences are thought to have effectively altered prehistoric subsistence patterns throughout the area. A broad-based hunting and gathering spectrum is thought to have evolved during these times by prehistoric cultures and flourished, with some cultural modifications, through the Late Prehistoric period. A wide variety of corner and side-notched projectile points and other stone tools characterize this long period of hunting and gathering subsistence. Unfortunately, while the remains of Archaic campsites are scattered throughout the region and predominate the material manifestations of the archaeological record, the diversity of sites, lithic assemblages, and the long time period still limit the understanding of Archaic lifeways. 
Late Prehistoric Period (ca. A.D. 1000 to European contact)

The Late Prehistoric period is thought to represent a continuation of earlier subsistence and cultural patterns that were distinctly modified by technological elements such as the manufacture of sandy, shell, and bone-temper ceramics and the introduction of the bow and arrow. How these materials qualitatively affected the related cultures is not yet clearly understood, although some modification of the subsistence and occupation patterns is assumed, due to increased efficiency of hunting methods and technology.

It is during the Late Prehistoric that littoral and inland or savanna aboriginal occupation patterns can be discretely identified. Corbin (1974) and MacNeish (1958) have identified the Rockport and Brownsville complexes, respectively, concentrated along the southern Texas coast during this general time period. Inland, or transphysiographic seminomadic patterns discussed earlier are thought to have centered around permanent water sources and riparian zones with specific seasonal movements to widely varying and distant natural resources. Faunal remains collected from Late Prehistoric campsites indicate an emphasis on smaller game such as rabbits and rodents but including deer and occasionally, bison and antelope (Lynn, Fox, and O'Malley 1977:41).

\section{HISTORIC BACKGROUND}

\section{Historic Indian Groups}

Historic Indian groups of southern Texas are known to have been composed of several distinct linguistic stocks, the most common groups associated with variations of Coahuilteco (which is understood only in the broadest terms). Other historic Indian groups are related to Athapaskan (Apache), Shoshonean (Comanche, Kiowa), and possibly Tonkawan and Wichita linguistic stocks. These latter groups were intrusive into the region during historical times. Early groups indigenous to the area were displaced (south/southeastward?), joined missions, or succumbed to the pressures of warfare and/or European epidemics. A detailed description of Coahuilteco groups known to have seasonally exploited the general area of eastern Duval and western Nueces Counties is presented by Campbell and Campbell (1981:7-39), and the reader is also referred to reports by Campbell (1975) and McGraw and Hindes (1987) for further general information on historic Indian groups of the general area.

\section{Spanish and Mexican Influence}

Spanish interests north of the Rio Grande began in the mid-16th century with politics, missions, and precious minerals. It was not until the mid-1700s, however, that efforts were made toward colonization of this vast frontier. The province of Nuevo Santander was formed in 1746 which included present-day northern Mexico and southern Texas (Mallouf, Baskin, and Killen 1977). By 1750 , several ranchos had been established on the north bank of the Rio Grande, and expansion gradually and sporadically worked its way northward. According to Bolton (1970), four roads crossed southern Texas during Spanish colonial times, and one, from Laredo to Goliad, may have crossed northwestern and north-central present-day Duval County, passing close to the survey area (Lynn, Fox, and O'Malley 1977:Fig. 16).

Little interest was historically shown in the general study area until the early 19th century when the area between the Rio Grande and the Nueces River became known as Llanos de las Mestinas, or Mustang Plain (Mallouf, Baskin, and Killen 1977). Before the founding of the Mexican Republic in 1821, the area was inhabited by a varied assortment of bandits, raiding Indians, and men who caught mustangs. Although poor soil and a lack of water detracted from colonization efforts, colonists were encouraged to occupy the area after the mid-19th century. By the time of the Texas Revolution, increased Indian depredations caused many of the Mexican inhabitants to flee southward toward Mexico, indirectly strengthening the Texas Republic's claim to the area, although the lands between the Nueces River and the Rio Grande were disputed territory until the close of the Mexican War in 1848 (Dobie 1929). 


\section{Ranching and Rustling}

The development of roadways in south Texas and the introduction of steamboats on the Rio Grande during the Mexican-American War greatly increased the area's potential for trade and ranching (Mallouf, Baskin, and Killen 1977:45). Although little actual military activity occurred in the area, the growth of the Confederacy and the subsequent Civil War also greatly increased commerce, and ranching soon increased as well (ibid.:47). One historian described the era, "the rancher replaced the priest and the soldier" (Myres 1969:15).

Probably the most influential among the ranchers was Richard King. King earned enough money running steamboats on the Rio Grande to purchase a 75,000-acre Spanish land grant of Santa Gertrudis in 1853 (Webb and Carroll 1952:531; Lea 1957). He continued to add to his holdings and, for a time, went into partnership with Mifflin Kenedy, another noted rancher. By the time of his death in 1895, King had amassed over 614,000 acres. One track north of the Santa Gertrudis unit and not contiguous to it was known as the San Leandro Ranch of about 8856 acres (ibid.). Located within the Mexican land grant of the same name, this property is only slightly east of the area surveyed. Because of border disturbances in the $1870 \mathrm{~s}$, the United States Cavalry kept a detachment near San Diego, on a portion of San Leandro, which King donated for use by the military (Lea 1957). At one point in 1874, depression forced King and other ranchers to increase wool production. Nueces and Duval Counties were at that time the leading producers of wool in Texas (ibid::30).

Bandito activities seemed to increase along with cattle ranching. Juan Nepomuceno Cortina, "the Red Robber of the Rio Grande" (or Cheno, as he was popularly called), was the most powerful and daring of the bandits (Dobie 1929:50). Dismissed from his lieutenancy in the Mexican army for selling government horses, Cortina murdered his Texan employer in 1847 and was soon stealing horses and cattle all over Texas. In 1859, he and his men captured Fort Brown at Brownsville. For more than 15 years afterward, he plundered and murdered, at times commanding hundreds of bandits (ibid.).

Border troubles were at their worst between 1871 and 1875 . Large-scale ranchers, like King and Kenedy, hired private rangers to help prevent thievery, and numerous unofficial law-enforcing groups like the one captained by Hines Clark in Duval County were organized (Dobie 1929). One example (ibid.:60) used to illustrate common bandito activities of the time probably took place in the vicinity of the area surveyed. In 1873, Caballo Blanco (one of Cortina's associates) and his men were stealing horses and skinning cattle in the then unorganized county of Duval. The bandits camped in the chaparral and sent word to the small town of San Diego to either bring enough money to buy the hides or enough men to skin the "hide peeler" (rustlers). Eleven Texas cowmen took the challenge:

Near the camp the Texans found the carcasses of 80 cattle recently killed and skinned; at another place they found 275 carcasses; at still another 360 carcasses. Not a great while afterwards Caballo Blanco and some of his skinners were "settled" (Dobie 1929).

Loss of cattle due to raiding was a common problem, and many ranchers, including King and Kenedy, filed government petitions setting forth their losses (ibid.:69; Lea 1957:411).

\section{Organization of Duval County}

Duval County was created in 1858 from parts of Nueces, Live Oak, and Starr Counties, but was not organized until 1876, when San Diego was named as county seat (Webb and Carroll 1952:531). The county was named for three brothers named Duval, who distinguished themselves variously at the Goliad Massacre, in the Texas Rangers, and in the state judiciary (ibid.:530-531).

The population in 1870 was 1083 citizens. In 1873, the railroad reached Duval County, and the population increased, reaching 8483 citizens by 1900 . Oil and gas were discovered at Piedras Pinta in 1903, but were not extensively exploited until the 1920s. In 1914, San Diego was the center of a Latin-American uprising, supposedly sponsored by Germany to help Mexico recover Texas; the movement collapsed upon discovery. Population increased to 17,500 in 1930 and had reached 20,565 in 1940, but dropped to 15,582 by 1950 . 


\section{Past Land Ownerships in the Survey Area}

A preliminary records search on past ownership titles of the study area was conducted in the Duval County Tax Collector-Assessor's Office and the Texas Land Office in Austin. The resulting data will be briefly reviewed.

The current study area encompasses approximately 4.6 sections of land (roughly 3000 acres). The earliest records relating to this property describe land given to the Houston and Great Northern Railroad Company "for laying a section of 100 miles main track and four and seven tenths miles of siding from the 25th mile post to a point in Houston County" (Texas Land Office n.d.).

The Houston and Great Northern Railroad Company obtained two sections of land in this manner, which are now portions of the Crews property. In 1872, the Houston and Great Northern Railroad Company sold the northern section of their holding (640 acres) to Ursino Ranjel (Raujel?) for $\$ 200$ in silver. The southern section of land was sold to Juan Adama (or Adamie) in 1874, also for $\$ 200$. The northern and northeastern sections of the current study area were originally state property (Public Free School and Asylum Land) and were homesteaded by Julian Reyes of San Diego in 1905. The southwest section of the survey area also originated as public lands and was homesteaded by Tiburio Perez and his wife Maria Enferriea(?) Davila de Perez in 1901. Property ownerships since that time are shown in Figure 2.

\section{RESEARCH DESIGN}

Prior to field work, several preliminary survey considerations were identified;

(1) the lack of permanent water sources in or near the study area inferred that potential sites would be related to upland functional activities;

(2) the lack of soil depth (Soil Conservation Service 1980) implied that most sites would be moderately to extensively eroded;

(3) if the sites were utilized as temporary hunting camps, a pattern of distribution should occur related to overlook areas and exposures of prevailing winds; and

(4) ethnographic accounts, as discussed by Campbell and Campbell (1981), suggested that extensive areas of prickly pear cactus once existed either in the study area or in its immediate vicinity. If the remains of such plant processing sites existed within the survey area, the lithic debitage from such sites was presumed to contain a higher number of nonprojectile type stone tools than those sites associated with temporary hunting overlook campsites.

Based on these considerations, a research problem to guide field surveying was devised. Reliable historical sources suggest that at least some archaeological sites in the study area may have been exploited for extensive plant processing activity in addition to the more commonly occurring extensive hunting activity. Identified sites and their collected materials should reflect these different activities: the majority of temporary hunting campsites would be expected to be located on high overlooks and positioned in relation to prevailing winds; and plant processing sites, regardless of their topographic locations, should contain a higher percentage of utilized debitage and discarded nonprojectile point lithic tools than hunting campsites. An increased frequency of fire-fractured burned rock clusters might also be expected at nonhunting, processing, or multifunctional sites. This hypothesis is difficult to prove by only survey data, but it was felt the information gathered by a survey with this hypothesis in mind could indicate the possibility that sites exhibiting a high percentage of utilized debitage were plant processing sites.

The field survey methods were directed toward the interpretation of the collected materials, particularly the lithic assemblages, on the basis of our hypothesis of past site activities. The presence or absence (and artifact frequencies) of specific lithic types (utilized, retouched tools, projectile points) was thought to represent a dependent variable, determined by the composition of the actual site materials, since these materials are dependent upon past 


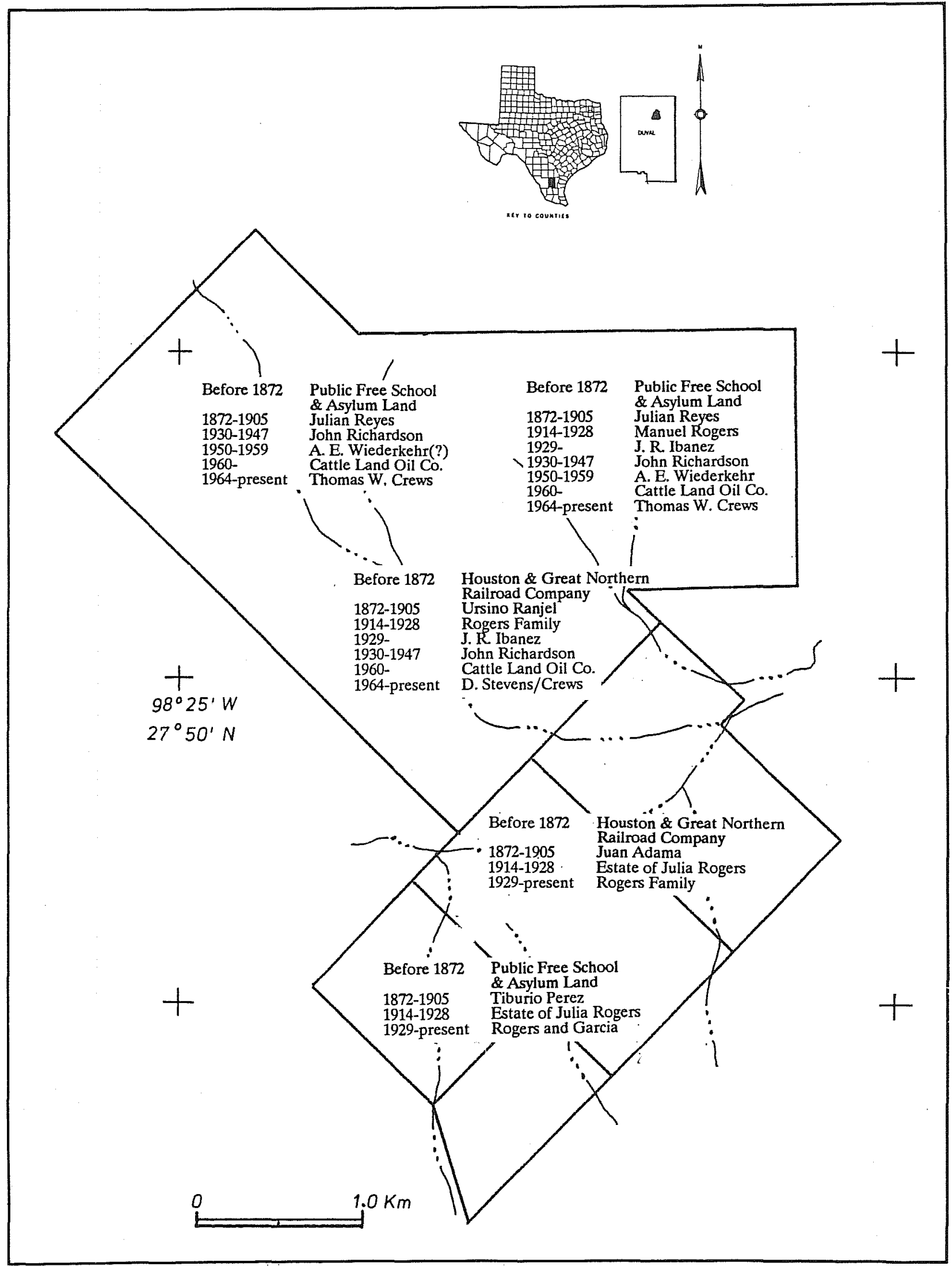

Figure 2. Land Ownership in the Study Area. 
activities (the last being considered an independent, influencing variable).* Stated simply, past activities determine the extent and variety of (in this case) lithic material remains. Site function is only secondarily influenced by the availability of local lithic resources.

Because of these preliminary survey considerations and site projections, four specific items of site evaluation were considered for each location:

(1) site locations were evaluated in relation to overlook characteristics and direction of prevailing winds;

(2) the types and frequencies of utilized and retouched debitage were of interest at each identified site, and care was taken to collect the largest possible surface sample of materials;

(3) the numbers and sizes of identified burned rock clusters were noted; and

(4) site condition, particularly in respect to erosion was also noted. Judgment sampling (Jelks 1975), in the form of $50-\mathrm{cm}^{2}$ shovel tests, was frequently employed to test for soil depth and buried deposits.

Based on these preliminary survey considerations, topographic and aerial maps were inspected; and a strategy of survey operations was composed, defined by (1) accessibility; (2) areas of high site potential; and (3) systematic survey procedures. A comparison of expected results, actual results, and a description of collected materials is presented in the following sections.

\section{SITE DESCRIPTIONS}

Twenty-five sites were identified, recorded, and assessed during the course of the survey. These sites are plotted in Figure 1. A brief summary of general site characteristics and recommendations for further work, if any, are discussed.

\section{SITE 41 DV 17}

Location: The site is located adjacent to and may extend northward beyond (unsurveyed) the northwestern fence line of the Crews property (fence runs northeast-southwest). The site is situated along the southern slope of a hilltop located slightly north and beyond the study area boundary.

Site description: A partially eroded, small burned rock cluster (hearth) was observed from a ranch road paralleling the fence line. Fire-fractured burned rock is lightly scattered throughout this area, and several fragments of lithic debitage, as well as a Perdiz arrow point, were collected. This site is oval and approximately $60 \mathrm{~m}$ in diameter. Site area may extend southeastward into extremely dense brush.

Type of site: light occupation; possibly multifunctional area

Elevation: 520 feet above mean sea level (msl)

Topography and soil: The site lies on the southern slope of a hill between 520-530 feet above msl. The soil is shallow and reddish to deep reddish in color. Vegetation (mostly thorny brush) reaches heights of ca. 6-7 feet and is quite dense.

\footnotetext{
*The model inherent in this proposition suggests that various site activities are indeed reflected in the archaeological record, particularly in the lithic components. While this assumption is open to a broad discourse in examining hunting and gathering social and economic systems (cf. Yellen 1977), the identification of site functions and predictions for distribution have been approached with some (apparent) limited success regionally by Gerstle, Kelly, and Assad (1978) and Fox (1977).
} 


\section{Site Descriptions}

Site condition: The cultural deposits are disturbed by road bulldozing and natural erosion.

Recommendations: No further work is recommended; site extensively damaged by road grading and natural processes.

\section{SITE 41 DV 18}

Location: The site is located adjacent to and along the northwest fence line of the Crews property (fence runs northeast-southwest). Portions of the site may extend northward of this fence line into unsurveyed property. This site is located on the southeastern slope of a hilltop which crests at the 500-foot contour line.

Site description: This site consists of scattered burned rock associated with a minimal amount of debitage (flakes and chips). No diagnostic artifacts or artifact fragments were recovered. This site is round and approximately $30 \mathrm{~m}$ in diameter.

Type of site: probably light, intermittent occupation

Elevation: $530-540$ feet above msl

Topography and soil: The site lies along the southern exposure of an upland slope which overlooks the major drainage in the area. The soil associated with this site is a medium red sandy loam. The surrounding vegetation consists of thick thorny brush 3-10 feet in height and extremely dense.

Site condition: Cultural deposits associated with this site have been eroded and disturbed through natural erosional processes as well as road maintenance activities.

Recommendations: No further work is recommended; site is extensively damaged by bulldozing and natural erosion.

\section{SITE 41 DV 19}

Location: This site is located in the northwest margins of the Crews property along the southern slopes of a large ridge complex, on the northern bank of a secondary, intermittent drainage.

Site description: The site consists of a moderate scatter of lithic debitage covering a radius of $75 \mathrm{~m}$. Also noted across the area were gray, sharply angled burned rocks. Subsequent shovel testing revealed an intact burned rock cluster approximately $55 \mathrm{~cm}$ in diameter and $5-10 \mathrm{~cm}$ below the surface, suggesting the presence of additional undisturbed materials and/or features. Two complete bifaces were recovered.

Type of site: possibly multifunctional and/or occupational area

Elevation: ca. 505 feet above msl

Topography and soil: The site lies on an upland slope overlooking the confluence of two small, intermittent drainages which flow southward. The soil is a fine reddish brown sandy loam, and the accompanying vegetation consists of dense thorny brush common to south Texas.

Site condition: Although the surface of the site has been exposed to erosional processes which have disturbed some cultural materials, subsurface testing suggests intact materials and/or features exist below the surface.

Recommendations: Although only a limited amount of subsurface examination has taken place at this site, such work has identified a buried feature and the potential for additional cultural deposits. In the opinion of the authors, this site may contain significant cultural deposits and should be considered potentially eligible to the National Register of Historic Places. As such, we recommend avoidance of this site area during future projected work: If this is not feasible, 
steps should be taken to more accurately determine the extent and significance of the cultural deposits.

\section{SITE 41 DV 20}

Location: This site is located on the southern slope of a hilltop in the eastern portion of the Crews property. The site is adjacent to the northwest fence line of this property. The site may extend beyond the survey area boundaries.

Site description: The site is characterized by a loose scatter of burned rock and debitage (flakes and chips). Oval in shape, the site is $20 \times 30 \mathrm{~m}$, with the long axis oriented along a northeast-southwest line. Two complete bifaces were recovered.

Type of site: probably light occupation; possibly multifunctional area

Elevation: ca. 500-510 feet above msl

Topography and soil: This site is located along the southern slope of a 550-foot hill. The soil associated with the site is a shallow, reddish brown to light brown fine sandy loam. This site is surrounded by heavy, dense thorny brush which reaches heights of 8-10 feet.

Site condition: The site is bisected by a fence line road and, as a result of road maintenance and natural erosional processes, is badly disturbed.

Recommendations: No further work is recommended; the site is extensively damaged through natural erosion and road maintenance.

\section{SITE 41 DV 21}

Location: This site is located in the northwestern portion of the Crews property on the same hillside as sites $41 \mathrm{DV} 17,41 \mathrm{DV} 18$, and $41 \mathrm{DV} 20$. It lies along the 520 -foot contour line and is approximately $300 \mathrm{~m}$ south of site $41 \mathrm{DV} 18$ and $350 \mathrm{~m}$ east-southeast of site $41 \mathrm{DV} 17$.

Site description: The site consists of three or four partially buried burned rock clusters which may or may not be interconnected as one. Debitage in the form of flakes and chips and one bifacially worked chopping tool were recovered. Oval in shape, the site is $75 \times 50 \mathrm{~m}$, with the long axis oriented along an east-west line.

Type of site: probably light occupation; multifunctional area

Elevation: ca. 525 feet above msl (central portion)

Topography and soil: The site is located on an upland slope between two intermittent drainages. The soil is a deep reddish sandy loam, and the surrounding vegetation consists of dense thorny brush which reaches heights of 8-12 feet.

Site condition: The site is partially buried, and erosional damage is evident.

Recommendations: Given the evidence of partially buried, eroding features, the authors recommend limited testing in the form of $1-\mathrm{m}^{2}$ and $2-\mathrm{m}^{2}$ hand-excavated test units to more accurately determine the significance and extent of cultural deposits. Such work is considered necessary to determine the potential National Register eligibility of 41 DV 21.

\section{SITE 41 DV 22}

Location: This site has both historic and prehistoric components. The site is located on the highest hilltop along the western fence boundary of the Crews property. 
Site description: The site, a historic dump area, consists of bottles, metal, and wood scraps as well as glass and ceramic fragments. In association with this dump are two concrete foundation slabs (see description of historic materials) which seem to be associated with some type of drilling activity. The site covers a rectangular area $100 \mathrm{~m}$ wide by $200 \mathrm{~m}$ long. Biface tool fragments were recovered.

Type of site: historic occupation; possibly light prehistoric occupation

Elevation: 500 feet above msl

Topography and soil: The site is located atop one of the highest hills in the area, and overlooks the northern slope of the hill. The hill slopes gradually to the north and east, with steeper slopes grading south and west. The immediate vicinity of the site is relatively clear of the underbrush species which dominate the survey area, having been replaced by mesquite trees (one of the few places in which such trees were noted). The soil is a reddish brown to brownish gray sandy loam.

Site condition: The prehistoric component of this site is widely scattered and ill-defined. The condition of the materials associated with the historic component is in a state of preservation sufficient for further studies.

Recommendations: No further work with respect to the prehistoric component is recommended. Further archival and records investigations do not show the historic component to be of significant cultural value to warrant further work. While no further work is recommended of either the prehistoric or historic component, it should be noted that these recommendations are based only on available material. Should further cultural evidences be uncovered during future construction, the proper authorities should be contacted.

\section{SITE 41 DV 23}

Location: The site is located on the western side of a south flowing intermittent drainage, south of the intersection of an east-west fence line and a northwest-southwest fence line in the northern portion of the Crews property. It is situated along the 500-foot contour line on the southeastern slope of a hill which crests at 510 feet above msl.

Site description: The location consists of a loose oval lithic debitage scatter associated with burned rock over an area approximately $30 \mathrm{~m}$ in diameter. One biface fragment was collected. The site dimensions may extend into the surrounding vegetation.

Type of site: lithic scatter; light occupational area

Elevation: ca. 505 feet above msl

Topography and soil: This site is on the western bank of an intermittent drainage which flows southward through the Crews property. The soil associated with this site is a medium red to light brown sandy loam, shallow in depth. Vegetation consists of dense, thorny brush reaching heights of 10-12 feet with occasional small clearings.

Site condition: The area is badly eroded, due in part to an old, unmapped roadbed which facilitates erosional activities.

Recommendations: While the site area is characterized by extensive erosion, considerations should be made regarding the possibility of buried deposits extending into dense brush in the immediate vicinity. Should such locations be impacted, the authors recommend limited testing in the form of $50-\mathrm{cm}^{2}, 1-\mathrm{m}^{2}$, and $2-\mathrm{m}^{2}$ hand-excavated units to determine the extent and depth of possible cultural deposits. Such work is considered a prerequisite for assessment of potential site eligibility to the National Register of Historic Places. 


\section{SITE 41 DV 24}

Location: This site is located along the northern boundaries of the central portion of the Crews property.

Site description: The site comprises a circular area approximately $150 \mathrm{~m}$ in diameter on an upland slope which forms the eastern bank of a secondary drainage. The site is bisected by a fence line maintenance road. Portions of the site may extend northward across the fence line and out of the survey area. A burned rock cluster was noted eroding out of the roadbed. Additional burned rock was observed scattered for $20-30 \mathrm{~m}$ downslope in the roadbed. Materials collected include two complete bifaces, one complete uniface, and one biface fragment, as well as flakes and chips.

Type of site: probably multifunctional and/or occupational area

Elevation: 510 feet above msl

Topography and soil: The site commands a good view of the upland slope from the east clockwise through the southwest. Present-day dense, thorny brush obscures most of this view. The soil is medium to deep red sandy loam.

Site condition: Although much burned rock and lithic debitage has been eroded and transported downslope (accelerated in more recent times by the roadbed), limited shovel testing indicated soil depths were sufficient to preserve intact cultural features below the surface.

Recommendations: Further testing in the form of hand-excavated $1-\mathrm{m}^{2}$ and $2-\mathrm{m}^{2}$ units are recommended to further assess site potential.

\section{SITE 41 DV 25}

Location: This site is located along the eastern boundary of the Crews property adjacent to the fence line. The site lies on the northeastern slope of a low hilltop which crests at 474 feet above msl. Part of the site lies within a roadbed which parallels the north-south boundary fence line.

Site description: This site is oval, measuring $50 \times 100 \mathrm{~m}$ oriented along a north-south axis. The site is characterized by a light scatter of lithic debitage consisting of flakes, chips, one biface fragment, and one complete biface.

Type of site: probably light, intermittent occupation; possibly multifunctional area

Elevation: ca. 465 feet above msl

Topography and soil: Soil is light gray to medium reddish tan sandy loam, shallow in depth. Vegetation is predominantly thick, dense thorny brush with occasional small clearings. Height of vegetation averages $4-5$ feet.

Site condition: The lithic debitage is thin and widely dispersed.

Recommendations: No further work is recommended due to badly eroded conditions.

\section{SITES 41 DV 26 AND 41 DV 27}

Location: Both sites are located on a high overview in the eastern portion of the Crews property and offer commanding views of both the eastern slope (41 DV 10) and the northern slope (41 DV 11).

Site description: Site $41 \mathrm{DV} 26$ is circular, approximately $100 \mathrm{~m}$ in diameter. Site 41 DV 27 is approximately $100 \times 150 \mathrm{~m}$ and oval in shape. While these sites are adjacent to one another and 


\section{Site Descriptions}

share similar cultural and topographic features, field observations and artifact concentrations suggest these sites are spatially discrete and distinct. At both sites, burned rock clusters, lithic debris scatters, and biface fragments were noted. In addition, four complete bifaces were recovered.

Type of site: Both sites represent possible multifunctional and/or occupational areas.

Elevation: Both sites are located on the 470 -foot contour line of a hill which crests at 479 feet. Site 41 DV 26 lies on the eastern slope, and 41 DV 27 lies on the northern slope.

Topography and soil: The soil at both sites can be characterized as shallow, reddish tan to medium red sandy loam. Vegetation is thick, dense thorny brush with occasional small clearings. Both sites are situated near the top of upland slopes.

Site condition: Erosional damage has scattered cultural materials downslope; however, due to the relatively large amount of burned rock, lithic debris, and debitage, these sites represent the largest concentration of prehistoric materials observed during the survey. There is a strong possibility that significant cultural materials may still be intact just below the surface.

Recommendations: Further testing in the form of hand-excavated $1-\mathrm{m}^{2}$ and $2-\mathrm{m}^{2}$ units to further assess site(s) limits and significance is recommended.

\section{SITE 41 DV 28}

Location: This site is located atop a low hill in the east-central portion of the Crews property. The hilltop overlooks intermittent drainages to the east and southwest.

Site description: The site consists of a thin, widely dispersed lithic scatter. The site is round and approximately $50 \mathrm{~m}$ in diameter. One uniface fragment was recovered.

Type of site: probably light occupational area

Elevation: 481 feet above msl

Topography and soil: The soil is a reddish brown sandy loam ranging in depth from shallow to moderately shallow $(10-20 \mathrm{~cm})$. Vegetation consists of dense, thorny brush of varying heights with occasional small clearings.

Site condition: The site area is eroded, and lithic debris are widely scattered.

Recommendations: No further work is recommended because the site is badly disturbed due to erosional processes.

\section{SITE 41 DV 29}

Location: This site is located on the southwestern slope of a hill in the east-central portion of the Crews property.

Site description: This site consists of a small, round lithic scatter approximately $30 \mathrm{~m}$ in diameter. Much of this scatter is eroding downslope along an old roadbed.

Type of site: probably light occupation; possibly multifunctional area

Elevation: $460-470$ feet above msl

Topography and soil: The soil is a reddish brown sandy loam with very little depth. Vegetation consists of dense, thorny brush with heights of 3-10 feet. 
Site condition: The site is eroding downslope along an old roadbed.

Recommendations: Due to the badly eroded conditions of the site, no further work is recommended.

\section{SITE 41 DV 30}

Location: This site is located on the southern slope of a hillside in the northwestern portion of the Crews property. The site overlooks the confluence of two drainages which flow southeastward through the property.

Site description: The site consists of a thin, widely dispersed lithic scatter. The site is round and $30 \mathrm{~m}$ in diameter. No diagnostic artifacts were recovered. One biface fragment was collected.

Type of site: light occupation; possibly multifunctional area

Elevation: ca. 490 feet above msl

Topography and soil: The site lies on the southern slope of the same hill as 41 DV 23 , between 490 and 500 feet above msl. The soil is grayish tan to yellowish tan sandy loam, shallow in depth. Low, sparse brush occurs downslope, grading into thick, thorny brush upslope with heights of 6-8 feet.

Site condition: The site is badly eroded; lithic debris are widely scattered.

Recommendations: Due to the badly eroded conditions of the site, no further work is recommended.

\section{SITE 41 DV 31}

Location: The site is located near the central portion of the northwest boundary of the Rogers property. The site overlooks an intermittent secondary drainage which flows northward into the main drainage channel.

Site description: This site is comprised of both historic and prehistoric components. The prehistoric component is represented by a thin scatter of lithic debitage. The historic component is represented by ceramic fragments as well as tin and glass fragments. None of these artifacts were diagnostic. The site is oval, and the historic materials covered an area $10 \mathrm{~m}$ in diameter, while the prehistoric materials covered an area $30 \mathrm{~m}$ in diameter. This site is bisected northwest to southeast by a sendero.

Type of site: The historic debris are scattered. The prehistoric materials may represent a light occupational area.

Elevation: 460 feet above msl

Topography and soil: The site is located on a gently sloping hillside characterized by reddish sandy loam with low, sparse brush and short-stemmed grasses.

Site condition: The site is badly disturbed due to erosional activities, and, more directly, geological testing activities along the sendero.

Recommendations: No further work is recommended.

\section{SITE 41 DV 32}

Location: The site is located in the southeast-central portion of the Rogers property. The site is on the eastern slope of an intermittent, northward flowing, secondary drainage. 
Site description: This site is composed of both historic and prehistoric components. The historic component is represented by multicolored glass fragments, while the prehistoric component is represented by lithic debitage in the form of flakes and chips as well as one thermally altered chert cobble. The site is widely scattered and round, with a diameter of approximately $50 \mathrm{~m}$.

Type of site: Scattered debris; the prehistoric materials may indicate a light occupational area with possible multifunctional usage.

Elevation: ca. $470-475$ feet above msl

Topography and soil: The soil is a yellowish red sandy loam. The topography is gently sloping with sparse to dense thorny brush and short-stemmed grasses.

Site condition: The site is badly eroded, and cultural materials are widely scattered due to natural erosional processes.

Recommendations: Due to the badly eroded condition, no further work is recommended.

\section{SITE 41 DV 33}

Location: This site is located along the fence line delineating the southeastern boundary of the Cardenas property. The site is an elongated oval measuring $150 \times 200 \mathrm{~m}$ and lies on the upper north slope of a hill which crests just outside of the survey area.

Site description: The site is a widely scattered, badly eroded prehistoric occupation area, which lies on the southern slope of a hill which crests at 530 feet above msl. Cultural materials were recovered over an area measuring $150 \times 200 \mathrm{~m}$. Northeast-southwest senderos transected the site area at $20-\mathrm{m}$ intervals. Materials collected include lithic debitage (flakes, chips), biface fragments, ground stone fragments, and one complete biface scraping tool.

Type of site: probably a multifunctional and/or occupational area

Elevation: $510-520$ feet above msl

Topography and soil: The site lies on the northern slope of a hill which crests at 530 feet above msl. The northern side slopes gently downward toward a secondary drainage system which crosses the property. The site overlooks this drainage to the west. The soil varies in depth from 5 to $20 \mathrm{~cm}$ and is a brownish red silty loam.

Site condition: The site has been badly eroded and subsequently disturbed by bulldozers employed to cut senderos which bisect the site area.

Recommendations: Due to erosional activities and bulldozing, no further work is recommended.

\section{SITE 41 DV 34}

Location: The site is located in the northwest-central portion of the Garcia property, midway along a gentle northward slope.

Site description: The site consists of a thin, round lithic scatter approximately $20 \mathrm{~m}$ in diameter. No diagnostic artifacts were recovered.

Type of site: lithic scatter

Elevation: 480 feet above msl

Topography and soil: The site lies on a gently declining slope on the northern side of a hill which is covered by low, dense brush with few small clearings. The soil is a dark reddish sandy loam. 
Site condition: The lithic debris is widely scattered, and the site is poorly defined due to erosional activities.

Recommendations: No further work is recommended due to excessive erosion.

\section{SITE 41 DV 35}

Location: The site is located in the north-central portion of the Rogers property, along the fence line of a plowed field.

Site description: The site is round and $20 \mathrm{~m}$ in diameter. The site consists of a thin scatter of historic materials which include undecorated whiteware ceramics and porcelain fragments. The site lies in the plow zone of a field associated with a historic homestead area.

Type of site: thin scatter of ceramic fragments

Elevation: 440 to 450 feet above msl

Topography and soil: The site is located in a gently sloping field with deep reddish brown sandy loam. No vegetation is present within the field boundaries. Mesquite trees are present along the field boundaries.

Site condition: The site is badly disturbed by historic agricultural activities.

Recommendations: No further work is recommended.

\section{SITE 41 DV 36}

Location: The site is located along the southeast fence line of the Crews property and is situated approximately midway up the southeast slope of a hill. The site is bisected by a fence maintenance roadbed, and portions of the site may continue across the fence line outside the survey area.

Site description: The site is characterized by partially buried burned rock clusters, lithic debitage, and lithic tools. Mussel shell fragments were also recovered. The cultural materials are scattered over an elongated oval area, $80 \times 120 \mathrm{~m}$.

Type of site: probably a multifunctional, occupational area

Elevation: ca. 480 feet above msl

Topography and soil: The site lies on an upland slope which slopes downward in a southeasterly direction, forming the northern bank of an intermittent drainage channel. The soil is a shallow, reddish sandy loam. The surrounding vegetation consists of dense, thorny brush of varying heights from 3-12 feet.

Site condition: The site has been transected by a roadbed which has facilitated and accelerated natural erosional processes. As a result, the cultural materials are badly scattered, and very little appears to remain intact.

Recommendations: Due to the poor condition of the site, no further work is recommended.

\section{SITE 41 DV 37}

Location: The site is on an upland slope on the southeast side of a hill located in the central portion of the Crews property. The site overlooks portions of one of the major intermittent drainages in the area. 
Site description: The site consists of a small area (approximately $75 \mathrm{~m}$ in diameter) of scattered lithic debris. No cultural features, such as burned rock clusters, were noted. No diagnostics were recovered. Two biface fragments were collected.

Type of site: lithic scatter; possibly light occupational area

Elevation: ca. 460-462 feet above msl

Topography and soil: The site rests on a small point located on a gentle slope which faces southeast overlooking a drainage channel at the point where the flow direction changes from southeast to an easterly direction. The soil is a reddish sandy loam ranging in depth from 5$10 \mathrm{~cm}$. Low, sparse brush and short-stemmed grasses dominate the area. The area appears to have been cleared of brush recently.

Site condition: Cultural materials are badly scattered due to erosion, accelerated in part by brush clearing which has denuded the slope.

Recommendations: Due to the badly eroded condition of the site, no further work is recommended.

\section{SITE 41 DV 38}

Location: The site is in the east-central portion of the Crews property and ca. $350 \mathrm{~m}$ downslope of site 41 DV 29.

Site description: The site is characterized by a lithic scatter associated with similarly scattered burned rock. The site is round, approximately $30 \mathrm{~m}$ in diameter, and widely scattered. Portions of the site may continue into surrounding areas of dense, inaccessible brush. The site is heavily eroded.

Type of site: light occupation; possible multifunctional area

Elevation: This site is located on the 460 -foot contour line above msl on a hill which crests at 479 feet above msl.

Topography and soil: The soil associated with this site is a reddish sandy loam, thin in depth. The soil lies on the eastern bank of a secondary intermittent drainage which flows southward. The site is surrounded by dense, inaccessible brush with occasional small clearings. The average height of the brush varies from 5-8 feet.

Site condition: The materials associated with this site are widely scattered due to heavy erosion. Portions of the immediate vicinity are heavily rutted.

Recommendations: Due to the badly eroded conditions of the site, no further work is recommended.

\section{SITE 41 DV 39}

Location: The site is located in the southwest-central portion of the Crews property on an upland slope which forms part of the southwestern bank of one of the intermittent drainages in the survey area.

Site description: The site consists of a circular area approximately $50 \mathrm{~m}$ in diameter. Associated cultural materials include lithic debris, burned rock scatters, and one distal (tip) biface fragment.

Type of site: probably light occupation; possibly multifunctional area

Elevation: The site is located along the 490 -foot contour line above msl on a hill which crests at 500 feet above msl. The site also occupies a small point just east of the main hilltop. 
Topography and soil: The soil associated with this site is a reddish sandy loam. The point on which the site is located is adjacent to a small, intermittent feeder drainage which flows northward into the major drainage system. Thick, dense brush of varying heights covers most of the site area. Isolated, small clearings are present, but few in number.

Site condition: The site is heavily eroded, and much of the associated materials have been disturbed by this erosion and the more recent mechanical activities associated with cutting senderos through the brushland.

Recommendations: Due to the severely disturbed nature of this site, no further work is recommended.

\section{SITE 41 DV 40}

Location: The site is located on a small point above an intermittent drainage in the western portion of the Crews property.

Site description: The site is circular, ca. $75 \mathrm{~m}$ in diameter. While badly eroded on the surface, shovel tests revealed that cultural materials in the form of an intact burned rock cluster lie $75 \mathrm{~cm}$ below the surface. Along the surface, lithic debitage in the form of flakes and chips were recovered. No diagnostic artifacts were collected.

Type of site: The site is possibly a light occupational locus buried under periodic alluvial deposits.

Elevation: 470 feet above msl

Topography and soil: The site is overlain by homogeneous soil which was tested to a depth of $95 \mathrm{~cm}$. The site lies within the runoff area of a secondary drainage system. The soil is a tan, fine-grained, clayey/silty type. The surrounding vegetation consists of sparse, low shrubbery and short to tall grasses.

Site condition: While the surface area has been subjected to erosion as well as concentrated watershed activity from the surrounding slopes, shovel tests indicate the possibility of an intact component below more recent alluvial deposits.

Recommendations: Further testing is recommended to assess the significance of the buried cultural materials. While shovel testing at the site has indicated that subsurface deposits exist in the area, a lack of diagnostic or otherwise significant cultural materials precludes accurate assessments of the site's potential eligibility to the National Register. Testing in regard to the concentrated buildup of depositional layers accumulated as a result of past geological activities is also recommended. In this regard, the site may provide information useful in reconstructing the sequence, intensity, and effects of past geologic episodes in this region.

\section{SITE $41 \mathrm{DV} 41$}

Location: The site is located in the west-central portion of the Cardenas property on a slope which forms the eastern bank of a northward flowing, secondary drainage.

Site description: The site is circular with a minimum diameter of $100 \mathrm{~m}$. More definite dimensions could not be determined due to the heavy, dense brush surrounding the site. The site is badly eroded and consists of the largest burned rock scatter encountered during the survey. A minimal amount of flakes and chips was also collected.

Type of site: possibly multifunctional area

Elevation: The elevation of the central portion of the site is approximately 450 feet above msl. 
Topography and soil: The site lies on a gentle slope which forms the eastern bank of a secondary drainage. This portion of the survey area is heavily transected by senderos. The soil is a yellowish tan to grayish tan compacted silty loam which is covered by short and tall grasses, as well as heavy dense brush ranging in height from 3-12 feet.

Site condition: The burned rock is badly scattered due to heavy erosion and mechanical activities employed to cut the sendero network.

Recommendations: No further work is recommended at this site.

\section{CULTURAL MATERIALS ANALYSIS}

During the course of this survey, cultural materials representing both historic and prehistoric activity were recovered for analysis. As each site, or isolated find (designated when no site was recorded but cultural materials recovered), was recorded in the field, the cultural materials associated with that site were individually bagged. These bags were then processed in the laboratory, and all materials were classified and inventoried. Table 1 depicts the distribution of lithic materials by site and category, and also indicates those sites where historic materials were found. Table 2 provides a morphological description of the prehistoric artifacts.

\section{PREHISTORIC MATERIALS}

Twelve bifacial tools, 13 biface fragments, one unifacial tool, two uniface fragments, 132 pieces of debitage (flakes, chips, chunks), and two ground stone fragments represent the prehistoric materials recovered. Specific processes and/or sequences employed in the manufacture of lithic tools are not discussed in this report. The interested reader is referred to reports by Crabtree (1972), Hester (1980:87-120), and Lynn, Fox, and O'Malley (1977:103, Fig. 40) for discussions concerning various steps in lithic tool manufacture, maintenance, and use. The appendix to this report provides definitions of the more common terms used in discussing lithic tools and their manufacture.

\section{Bifaces}

Twelve complete bifacial tools and 13 biface fragments were recovered during the survey. Of this total, six were made from materials other than a milky white chalcedony, which seems to have been the primary lithic resource. Virtually all the debitage recovered was made of this material. Table 2 provides morphological and material characteristics for each biface and fragment. Figure 3 depicts eight of these specimens. Four specimens are discussed individually.

Specimen 41 DV 17-1 (Fig. 3,a)

Specimen $41 \mathrm{DV} 17-1$ is the most complete projectile point in the collection. Although this specimen is bifacially worked and the Perdiz arrow point typically unifacial, the extended barbs and the remainder of the contracting stem, as well as the size of the artifact, suggest it should be classified as Perdiz. This would date the point as Late Prehistoric (ca. A.D. 1000 until the time of European contact). See Hester (1980:104, Specimen k) for an example.

Specimen 41 DV 21-1 (Fig. 3,b)

Specimen 41 DV $21-1$ is the largest biface in the collection. It is a large, fist-sized, reddish brown quartzite cobble, bifacially worked along one edge. This same edge exhibits signs of battering or heavy use, typical of a chopping tool described by Hester (1980:114). 
TABLE 1. DISTRIBUTION OF COLLECTED CULTURAL MATERIALS

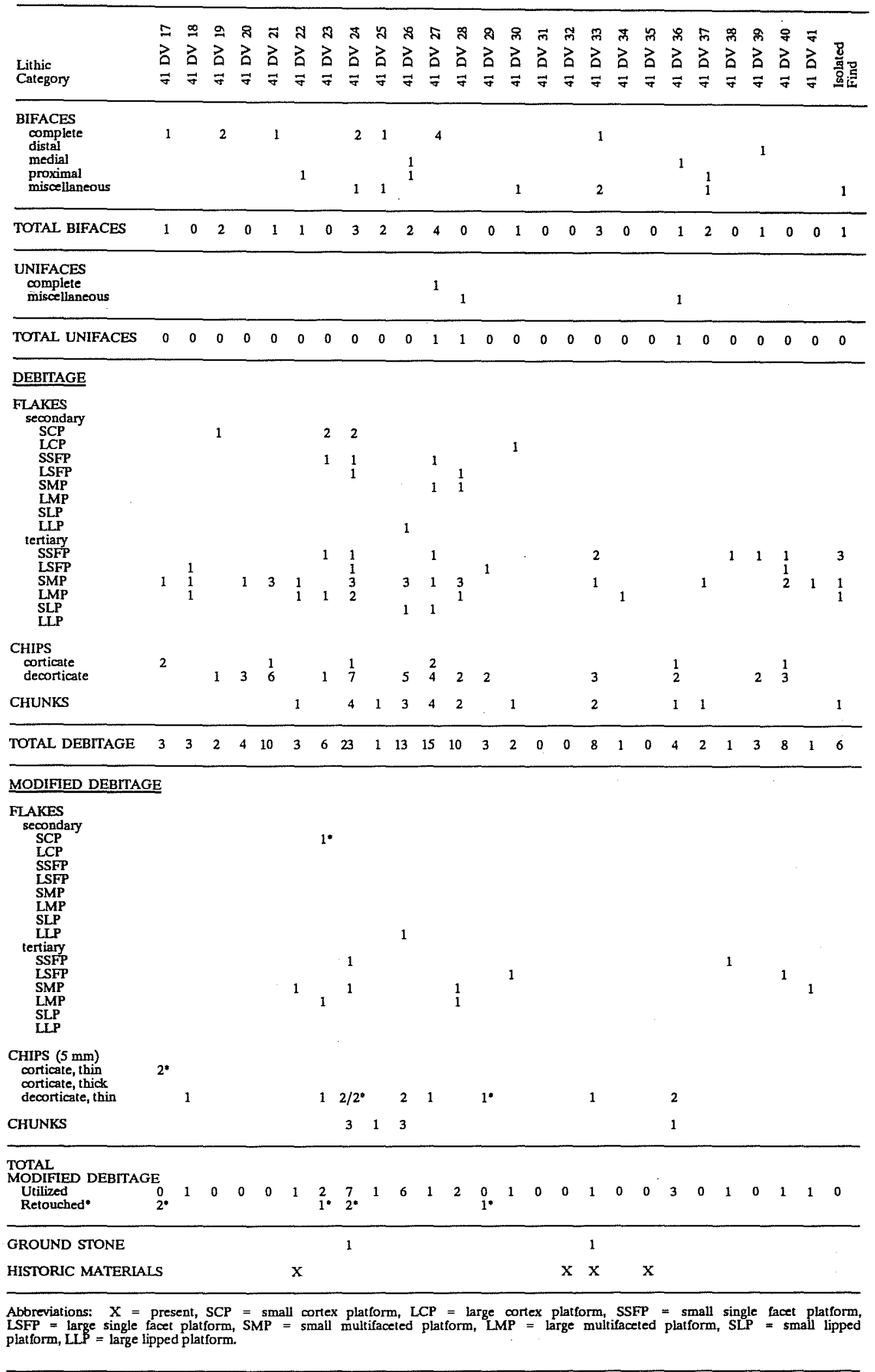


TABLE 2. DESCRIPTION OF LITHIC ARTIFACTS

\begin{tabular}{|c|c|c|c|c|c|c|}
\hline Artifact Type & $\begin{array}{l}\text { Site-Artifact } \\
\text { Number }\end{array}$ & $\begin{array}{l}\text { Length } \\
(\mathrm{cm})\end{array}$ & $\begin{array}{l}\text { Width } \\
(\mathrm{cm})\end{array}$ & $\begin{array}{l}\text { Thickness } \\
(\mathrm{mm})\end{array}$ & $\begin{array}{l}\text { Weight } \\
(\mathrm{g})\end{array}$ & Description \\
\hline complete biface & 41 DV $17-1$ & 2.4 & 1.6 & 3 & 0.7 & $\begin{array}{l}\text { Perdiz-like arrow point; bifacially worked, barbs } \\
\text { intact, basal portion missing (Fig. } 3, a \text { ) }\end{array}$ \\
\hline complete biface & 41 DV $19-1$ & 3.8 & 2.1 & 10 & 8.4 & Oval scraper; steeply beveled \\
\hline complete biface & 41 DV $19-2$ & 5.3 & 3.4 & 18 & 27.6 & Subtriangular, multifunctional \\
\hline complete biface & 41 DV $21-1$ & 8.4 & 7.8 & 42 & 309.0 & $\begin{array}{l}\text { Hand-held chopping tool; bifacially worked along one } \\
\text { edge; edge battering evident; reddish brown quartzite } \\
\text { (Fig. 3,b) }\end{array}$ \\
\hline complete biface & 41 DV $24-1$ & 3.2 & 2.6 & 9 & 7.4 & $\begin{array}{l}\text { Triangular scraping tool; all three sides steeply } \\
\text { beveled; Olmos tool(?) (Fig. } 3, \text { d) }\end{array}$ \\
\hline complete biface & 41 DV $24-2$ & 8.6 & 4.0 & 18 & 67.0 & $\begin{array}{l}\text { Elongated, multifunctional tool; reddish brown } \\
\text { chalcedony; edge battering evident along one edge (Fig. } \\
3, c \text { ) }\end{array}$ \\
\hline complete biface & 41 DV $25-1$ & 3.3 & 3.8 & 11 & 13.5 & $\begin{array}{l}\text { Triangular form with two steeply beveled sides; multi- } \\
\text { functional }\end{array}$ \\
\hline complete biface & 41 DV $27-1$ & 2.9 & 1.8 & 8 & 3.4 & $\begin{array}{l}\text { Tan chert; alternately beveled sides, triangular } \\
\text { (Fig. } 3, f)\end{array}$ \\
\hline complete biface & 41 DV $27-2$ & 3.8 & 2.2 & 10 & 7.6 & $\begin{array}{l}\text { Oval scraper; multifunctional; steeply beveled along one } \\
\text { half }\end{array}$ \\
\hline complete biface & 41 DV 27-3 & 2.7 & 2.3 & 14 & 8.5 & $\begin{array}{l}\text { Thick, irregular biface; subtriangular; heavy edge } \\
\text { battering along one edge (Fig. } 3, \mathrm{~h} \text { ) }\end{array}$ \\
\hline complete biface & 41 DV $27-4$ & 3.2 & 1.8 & 18 & 12.6 & $\begin{array}{l}\text { Thick, round, irregular biface; edge wear evident along } \\
\text { one edge (Fig. } 3, \mathrm{~g} \text { ) }\end{array}$ \\
\hline complete biface & 41 DV 33-1 & 3.4 & 2.3 & 12 & 11.2 & $\begin{array}{l}\text { Thick, subtriangular; edge wear evident along the two } \\
\text { lateral edges; edge battering evident along basal edge }\end{array}$ \\
\hline biface fragment & 41 DV $22-1$ & 2.8 & 4.8 & 20 & 25.2 & $\begin{array}{l}\text { Heavily patinated; appears to be preform(?) base } \\
\text { fragment }\end{array}$ \\
\hline biface fragment & 41 DV 24-3 & 3.4 & 2.0 & 18 & 9.1 & $\begin{array}{l}\text { Irregular shape; edge damage encompassing one half of } \\
\text { circumference may suggest subsequent use after fracture; } \\
\text { miscellaneous fragment }\end{array}$ \\
\hline biface fragment & $41 \mathrm{DV} 25-2$ & 2.5 & 2.5 & 12 & 7.6 & Miscellaneous fragment \\
\hline biface fragment & 41 DV $26-1$ & 1.6 & 1.9 & 7 & 2.3 & Medial fragment \\
\hline biface fragment & $41 \mathrm{DV} 26-2$ & 2.4 & 2.0 & 6 & 4.0 & $\begin{array}{l}\text { Proximal preform basal fragment; some tan cortex along } \\
\text { one edge; base is convex (Fig. } 3, \mathrm{e} \text { ) }\end{array}$ \\
\hline biface fragment & 41 DV $30-1$ & 3.1 & 2.4 & 18 & 12.8 & $\begin{array}{l}\text { Appears to be basal fragment from thick biface(?); } \\
\text { miscellaneous fragment }\end{array}$ \\
\hline biface fragment & 41 DV $33-2$ & 3.0 & 2.2 & 18 & 10.0 & Miscellaneous fragment \\
\hline biface fragment & 41 DV 33-3 & 1.5 & 1.4 & 4 & 0.7 & Miscellaneous fragment \\
\hline biface fragment & 41 DV $36-1$ & 2.8 & 2.2 & 6 & 4.4 & Medial fragment; brownish tan chert \\
\hline biface fragment & 41 DV $37-1$ & 2.5 & 3.3 & 10 & 9.6 & Proximal fragment \\
\hline biface fragment & 41 DV $37-2$ & 2.9 & 2.6 & 11 & 6.7 & Miscellaneous fragment \\
\hline biface fragment & 41 DV 39-1 & 3.4 & 3.1 & 4 & 3.2 & Thin, distal fragment; cryptocrystalline material \\
\hline biface fragment & $\begin{array}{l}\text { Isolated } \\
\text { Find } 4\end{array}$ & 3.3 & 2.2 & 14 & 9.3 & $\begin{array}{l}\text { Miscellaneous fragment; lightly patinated, brownish } \\
\text { chert }\end{array}$ \\
\hline uniface & 41 DV $27-5$ & 4.0 & 2.9 & 16 & 20.5 & $\begin{array}{l}\text { Subrectangular, steeply beveled edges with edge wear } \\
\text { evident; cortex along dorsal ridge (Fig. } 3, \mathrm{i} \text { ) }\end{array}$ \\
\hline uniface & 41 DV 28-1 & 3.7 & 2.9 & 16 & 14.0 & Triangular; retouch/use evident along base and one side \\
\hline uniface & 41 DV 36-2 & 2.8 & 2.5 & 16 & 4.9 & $\begin{array}{l}\text { Triangular; steeply beveled edge with retouch/use } \\
\text { evident; some discoloration evident (possibly thermal } \\
\text { alteration) }\end{array}$ \\
\hline ground stone & 41 DV 24-4 & 2.1 & 1.3 & 10 & - & Tan; smooth on both flat surfaces \\
\hline ground stone & 41 DV $33-4$ & 8.7 & 5.6 & 20 & - & $\begin{array}{l}\text { Whitish gray; plano-convex when viewed from the end } \\
\text { (depression } 4 \mathrm{~mm} \text { deep); smooth on both flat surfaces; } \\
\text { longitudinal striations on plano-convex surface }\end{array}$ \\
\hline
\end{tabular}

Note: All measurements represent maximum values (i.e., maximum thickness, maximum width, etc.). When artifact orientation could not be determined, the larger value was assigned as length. 

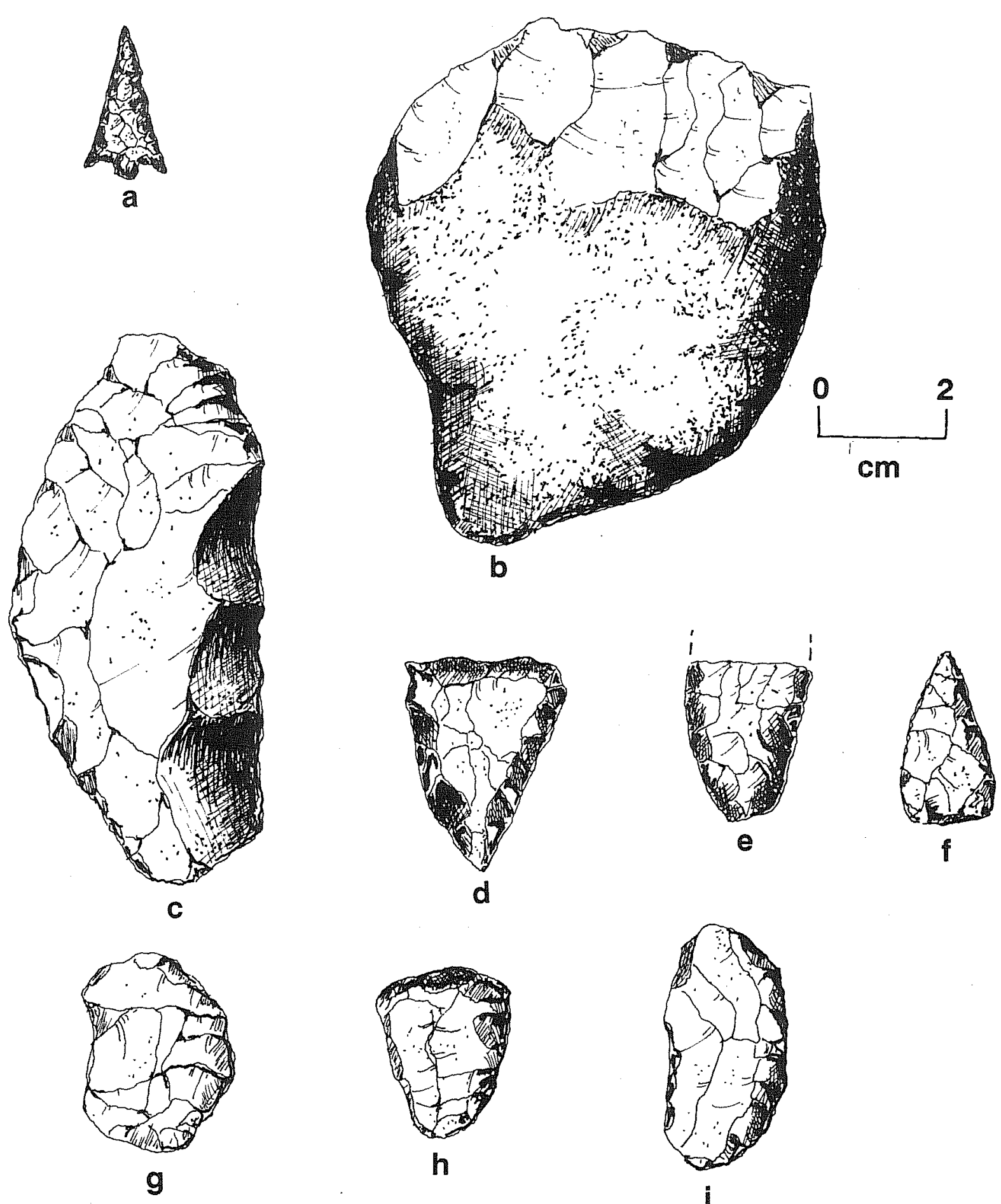

Figure 3. Selected Artifacts from the Duval County Survey. a, Specimen 41 DV 17-1 medial fragment arrow point; b, 41 DV 21-1 bifacially flaked quartzite cobble; c, 41 DV 24-2 crude bifacial tool; d, 41 DV 24-1 steeply beveled chalcedony tool; e, 41 DV 26-2 proximal portion of small biface; f, 41 DV 27-1 alternately beveled biface; g, 41 DV 27-4 thick irregular biface possibly formed from exhausted core; $h, 41$ DV 27-3 thick irregular biface possibly formed from exhausted core; i, 41 DV $27-5$ uniface. 
Specimen 41 DV 24-1 (Fig. 3,d)

Specimen 41 DV 24-1, a triangular biface tool with three sharply beveled edges, is similar to the Olmos tool common in Duval County and south Texas, and can be compared to the Olmos tool illustrated by Hester (1980:113, Fig. 5.14,b). It probably was used as a scraping tool (ibid.:114).

\section{Specimen 41 DV $27-1$ (Fig. 3,f)}

Specimen 41 DV $27-1$ is made of a tan chert. The sides are alternately beveled, and the base has been thinned. It may be an arrow or projectile point in the preform stage (intermediate stage prior to final shaping); however, the uniformity of workmanship of all the surfaces suggests a completed tool. If so, it may have served as a scraping or cutting tool with the basal edge utilized as the working edge and the pointed end used to facilitate hafting. In this case, the beveled surfaces may have served to prevent the point from rotating or twisting in the shaft.

\section{Unifaces}

One complete uniface (Specimen 41 DV 27-5; Fig. 3,i) and two uniface fragments (Specimens 41 DV 28-1 and 41 DV 36-2) were recovered during the course of the survey. Unifacial tools are typically fashioned by trimming or flaking the dorsal (outer) side while leaving the ventral (interior) side smooth. Specimen 41 DV 27-5 exhibits flaking across the dorsal surface with some cortex (outer covering of a cobble) remaining. Its ventral (side opposite cortex) side is smooth with a pattern of minute hinge fractures and/or flake scars along the edges. This pattern is a typical indication of use-wear. Unifacial fragment 41 DV 36-2 (not illustrated) exhibits some discoloration, which suggests thermal alteration (utilization of heat in the manufacturing process).

\section{Ground Stone}

Two ground stone fragments (Specimens 41 DV 24-4 and 41 DV 33-4) were recovered during the survey. Both exhibited smooth flat sides. A tactually smooth, sometimes glassy condition is typical of stones used for crushing or grinding (cf. Hester 1980:115-120). The plano-convex form of Specimen 41 DV 33-4 (not illustrated) and the minute striations within the depressed area suggest that this specimen is a metate fragment. These characteristics are typical of metates, which serve as the basin or host rock upon which grain, seeds, etc., are placed and against which a hand-held stone (called a "mano") is rubbed to crush the vegetal matter.

\section{Lithic Debitage}

Debitage consists of flakes, chips, and chunks resulting from lithic manufacturing activities. Such debitage exhibits different characteristics which vary with the stage of manufacture. For example, during the initial reduction, cortex-bearing debitage is common, while during the final shaping, small decorticate chips and flakes are common. There is also some degree of size variation, although not absolute, in the manufacturing sequence ranging from large, bulky fragments removed during initial rough shaping to the tiny, more numerous flakes and chips removed during the final shaping (when the need for precision and detail is increased). Debitage were also selected for use as part of the aboriginal tool kit, resulting in modified debitage which consists of pieces simply picked and used without further shaping, as well as other pieces which were marginally retouched to achieve a desired shape or angle. These latter pieces are commonly referred to as trimmed flakes and can be distinguished from unifaces, which are typically worked across one entire surface.

A total of 132 pieces of debitage was collected during the survey. Classification of these materials is recorded in Table 1. Each piece was examined under low magnification (10-15X) for modification through use and/or other edge alteration. Of the 132 pieces of debitage recovered, $62(47 \%)$ were flakes, $49(37 \%)$ were chips, and $21(16 \%)$ were chunks. Of 62 flakes, $14(23 \%)$ were secondary, and $48(77 \%)$ were tertiary. There were no primary flakes. 
The modified debitage (utilized and retouched) totaled 35 pieces. This comprised $26.5 \%$ of the total debitage. Of the 35 pieces of modified debitage, 12 were flakes, 15 were chips, and 8 were chunks. These figures convert to $34 \%, 43 \%$, and $23 \%$, respectively, of the total modified debitage. They also represent $8 \%, 11 \%$, and $6 \%$, respectively, of the total debitage (132) collected during the survey.

It is significant to note the two largest categories of debitage are the tertiary flakes and the decorticate chips. As can be expected, these are also the two largest categories of modified debitage. The small multifaceted platform tertiary flake and the thin decorticate chip are the two types of debitage which are most often modified.

As noted earlier, almost all of the debitage recovered during the survey was of a white chalcedony identical to that used to manufacture the bifacial and unifacial tools. No chert materials or outcrops were located during the survey which could have served as the source of this material. With this in mind and considering the relatively small number and size of lithic tools, the low volume of debitage and the large percentage of small decorticate chips and tertiary flakes to the total debitage, lithic activities apparently emphasized resharpening or reworking existing tools until they became unsuitable for use. Additionally, debitage byproducts from these activities seem to have been reused whenever possible to complement the limited supply of tools. These comments are speculative and are not intended to provide a conclusive interpretation of the lithic activities of prehistoric peoples who may have occupied the survey area. Additional field work (e.g., site excavations) may provide more conclusive insight in this area (see the Recommendations section of this report).

\section{HISTORIC MATERIALS}

A small quantity of historic materials was collected during the survey. Table 3 provides an inventory, by site, of the materials recovered. The majority of the materials recovered could not be classified because they lacked distinguishable or unique characteristics. However, some information can be offered with respect to artifacts from 41 DV 22, 41 DV 35, and Isolated Finds 8 and 13. These artifacts can be grouped into the following categories: glassware, ceramics, automotive accessories, and firearm accessories.

\section{Glassware}

One milk glass jar base and nine milk glass fragments were recovered. Neither the jar nor the fragments could be identified as to maker. Six fragments of a thick molded glass (three blue and three opaque) were identified as electrical insulators used in powerlines. These could not be related to any particular historic activity. In addition, two flat, clear glass fragments were recovered from $41 \mathrm{DV} 35$. They may be associated with the dwelling located approximately 75 yards southwest of the site. This dwelling is still in use intermittently.

\section{Ceramics}

A total of 25 ceramic fragments (sherds) was recovered. Comments can be made about two undecorated, molded whiteware fragments; a molded, hand-painted whiteware fragment from 41 DV 22; lead-glazed stoneware fragments from 41 DV 35; and Isolated Find 8. There were no distinguishing features on the remaining ceramic artifacts.

Undecorated whiteware has been in use throughout most of the 19th and 20th centuries, reaching its peak in popularity around the turn of the century. According to Anne A. Fox (personal communication), molded patterns and other types of decoration on whiteware became more popular around the 1920s and later. This time period is compatible with the information derived from automotive accessories recovered from the same site. The two lead-glazed stoneware fragments from 41 DV 35 and Isolated Find 8 can be assigned to the late 19th century or very early 20th century. Stoneware was used to store liquids, and the use of stoneware faded out with the increased popularity and use of glass bottles. According to McClinton (1951:53-58), stoneware was popular until the 1900s. Anne A. Fox (personal communication) also assigns the decline of stoneware to this period. 
TABLE 3. INVENTORY OF HISTORIC MATERIALS

Site

Description

41 DV 22

1 undecorated whiteware tea pot (opening diameter $8.5 \mathrm{~cm}$, maximum diameter $10.5 \mathrm{~cm}$ )

2 undecorated whiteware rim sherds with molded pattern

4 miscellaneous undecorated whiteware fragments (includes 2 curved fragments)

1 hand-painted molded whiteware fragment

1 milk glass jar base $(3 \times 3 \mathrm{~cm}$, height $3.5 \mathrm{~cm})$

2 Champion spark plugs (model numbers 2160 and 1720)

41 DV 31

5 milk glass fragments

41 DV 32

3 thick molded blue glass fragments

3 thick molded opaque glass fragments

41 DV 35

3 undecorated whiteware rim fragments

4 miscellaneous undecorated whiteware fragments

3 milk glass fragments

2 miscellaneous clean glass fragments

1 lead-glazed stoneware fragment

Isolated Find 3

1 miscellaneous undecorated whiteware fragment

Isolated Find $7 \quad 1$ miscellaneous undecorated whiteware fragment

1 miscellaneous milk glass fragment

Isolated Find $8 \quad 1$ undecorated whiteware rim sherd

4 miscellaneous whiteware fragments

1 lead-glazed stoneware sherd with banded slip (brown bands on orange base)

Isolated Find 9

1 undecorated whiteware rim sherd

Isolated Find 13

1 lead ball (weight $8.8 \mathrm{~g}$, diameter $1.2 \mathrm{~cm}$ ) 


\section{Automotive Accessories}

Two Champion brand spark plugs (numbers 2160 and 1820) were recovered from 41 DV 22 . Steve Straub (personal communication) reported that these models were manufactured between 1935 and 1941. He stated that they probably were used by 1941 , but advised that the period of use could have continued until 1945.

\section{Firearm Accessories}

One lead ball was recovered; one surface had been flattened. This ball also exhibits evidence of having been manually trimmed along its circumference. James E. Ivey (personal communication) identified the ball as having been hand molded (the edge trimming being a necessary step in such manufacture). Hand-molded lead balls were common until the advent of the cartridge load which was mass produced about the time of, and during, the Civil War, only to be quickly replaced by the breech loading rifle. According to Peterson (1962):

Practical centerfire cartridges with inside primers were made in England as early as 1852 but were ultimately perfected by Col. Hiram Berdan, of Civil War Sharpshooter fame, and by Col. Edward M. Boxer of the British Royal Laboratory in 1866. There has been no major change since. The metallic cartridge had reached its fully developed state and the separate prime guns had passed.

This is not to imply that this ball had to have been used prior to the Civil War, since no doubt such weapons continued to be popular into the late 1800s.

\section{SUMMARY AND RECOMMENDATIONS}

Prehistoric sites identified during the course of survey work may be described as small, temporary occupation sites presumably related to as yet unspecified special activities such as plant processing or other extended hunting and gathering tasks. All of the recorded sites were small (less than $250 \mathrm{~m}$ in diameter) and were associated with hilltops and overlooks. The prehistoric sites, are thought to be representative of the transphysiographic resource exploitation of early hunters and gatherers. The recognition of--in this case--substantial exploitation of upland natural resources is critical to future regional research concerning postulations of group territories and the identification of seasonal resource areas. The collection of surface-scattered lithic debris became a significant feature of the survey operations, since no indigenous chert was noted, and all chipping debris, as such, was considered intrusive. Since the materials often consisted of only a handful of flakes and chips per site, these were presumed to be related to resharpening or tool modification functions. An unusually high percentage of the material (in excess of $80 \%$ ) was composed of an opaque, milky-white chalcedony. This was apparently a preferred working material. Given the types of sites and the lack of raw materials, the flake debris and other associated lithic artifacts may represent the discards from small portable prehistoric tool kits (e.g., projectile points, scrapers, knives).

Following the completion of field work, several common site characteristics were noted:

1. Prehistoric site locations were distinctly upland related. Although several intermittent drainages were found in the study area, including (dry) Los Ineinitos Creek, an intensive on-ground inspection along the lower elevations did not reveal any associated occupations. activities.

2. Identified sites were quite discrete, suggesting only limited or temporary site

3. The chipped stone collection from the sites, as a whole, was quite small and was characterized by a lack of chronologically diagnostic projectile points. Only one small projectile point fragment was collected (from site $41 \mathrm{DV} 17$ ).

4. Several sites, although lacking even a moderate amount of lithic debris, contained a number of small burned rock clusters and/or scattered eroding hearths (41 DV 18, 41 DV 19, 
41 DV 26, and 41 DV 27). The abundance of this burned caliche at these locations implies either a larger site population than indicated by the frequency of lithic debris or much more recurrent exploitation of specific locations. In either case, the amount of scattered, fire-fractured rock suggests activities not directly related to lithic processes.

5. Surprisingly, a few sites did indicate the possibility of moderate soil deposits (e.g., site $41 \mathrm{DV} 40$ ). Although the soil was generally shallow and less than $30 \mathrm{~cm}$ deep, the possibility of buried cultural deposits does exist in some areas. The significance of the buried deposits lies primarily in the potential to more clearly define site activities and seasonality of use.

The sites identified during this survey are quite distinct from the previously recorded sites in Duval County (Hester 1971; Prewitt and Nance 1980). Although some examples of large, multifunctional, multicomponent occupations are often located near water sources, all those in the Chevron properties appear to be specialized activity centers or satellite sites, of possibly larger occupation sites in the vicinity, perhaps located along nearby San Diego Creek.

The collected lithics represent a somewhat unusual sample. Although only 132 pieces of debris were collected (an extremely small amount for the area surveyed), this nonetheless represents the total amount of observed surface materials.

Tabulation (Table 4) of overview directions of all the sites identified suggests that there were just as many with overviews toward the south (16) as there were sites facing north (15). More accurately, practically all of the sites overlook the adjacent drainages; sites in the southern survey area have exposures northward toward drainages, while the sites elsewhere face south. Sites are located predominantly on the mid to lower slopes of hilltops (average elevation at 480 feet), and only three sites (sites 41 DV 26,41 DV 27, and 41 DV 28) were on actual hilltops. It should be noted that scattered fire-fractured burned rock was often observed without any associated cultural materials, and conversely several isolated finds of a single flake or chip were also found.

Five sites possessed relatively larger collections of lithic debris and/or utilized lithic materials: 41 DV 24, 41 DV 26, 41 DV 27, 41 DV 28, and 41 DV 38. It is interesting to note the latter four are spatially proximate. These sites, as well as 41 DV 18 and 41 DV 19 also have a relatively higher frequency of burned rock scattered across the ground surface than any of the other identified sites. Although subsurface examinations would contribute much to a clearer understanding of these sites, preliminary observations suggest they may represent associated nonlithic activities. It may be reasonable to assume these sites are related to those nonhunting/overlook sites postulated earlier in the Research Design.

In summary, 25 prehistoric and historic sites were recorded during the survey. Five sites (41 DV 19, 41 DV 24, 41 DV 26, 41 DV 27, 41 DV 40) are recommended for further work, if adverse impact is to occur (Table 5). Limited testing in the form of $1-\mathrm{m}^{2}$ and $2-\mathrm{m}^{2}$ hand-excavated units, screened through $1 / 4$-inch or $1 / 8$-inch wire mesh, is suggested at these sites to determine potential eligibility for nomination to the National Register of Historic Places. Based on a preliminary assessment of field work and a review of collected materials, no further work is recommended for the remaining 20 sites. It must be noted that these recommendations are based on a preliminary assessment only; if additional sites are discovered during the course of future mining operations, Chevron is urged to contact the federal agency permitting or licensing the project, the Office of the Secretary of the Interior, the Texas Historical Commission, and the CAR-UTSA for determination of their cultural significance. 
TABLE 4. ELEVATIONS AND OVERVIEW DIRECTIONS OF ARCHAEOLOGICAL SITES

\begin{tabular}{ccl}
\hline Site & $\begin{array}{c}\text { Approximate } \\
\text { Elevation } \\
\text { Number }\end{array}$ & \\
(feet above msl) & Overview Direction \\
41 DV 17 & $520-530$ & \\
41 DV 18 & 530 & SE, S, SW \\
41 DV 19 & $500-510$ & N, E, S \\
41 DV 20 & $500-510$ & E, S, W \\
41 DV 21 & $520-530$ & SE, S, SW \\
41 DV 22 & 500 & E, S \\
41 DV 23 & $500-510$ & W, N, E \\
41 DV 24 & $510-520$ & E, S \\
41 DV 25 & $460-470$ & E, S \\
41 DV 26 & 470 & N, W, S \\
41 DV 27 & 470 & N, E, S \\
41 DV 28 & 480 & NW, N, NE, E \\
41 DV 29 & 460 & all directions \\
41 DV 30 & 490 & NW, W, SW \\
41 DV 31 & 460 & S, W, E \\
41 DV 32 & 470 & N, E, S \\
41 DV 33 & 500 & NW, N, NE \\
41 DV 34 & 480 & NW, N, NE \\
41 DV 35 & 460 & NW, N, NE \\
41 DV 36 & 480 & NW, N, NE \\
41 DV 37 & 460 & NE, E, SE \\
41 DV 38 & 460 & W, S, E \\
41 DV 39 & 490 & W, S, E \\
41 DV 40 & N, E, SE \\
41 DV 41 & NW, N, E \\
& & \\
\hline
\end{tabular}

Note: Maximum elevation $=590$ feet above msl; minimum elevation $=450$ feet above $\mathrm{msl}$, average site elevation $=480$ feet above $\mathrm{msl}$. 
TABLE 5. RECOMMENDATIONS

\begin{tabular}{|c|c|c|}
\hline Site Number & Type of Site & Recommendations \\
\hline 41 DV 17 & Prehistoric & No further work recommended \\
\hline 41 DV 18 & Prehistoric & No further work recommended \\
\hline 41 DV 19 & Prehistoric & Limited testing recommended \\
\hline 41 DV 20 & Prehistoric & No further work recommended \\
\hline $41 \mathrm{DV} 21$ & Prehistoric & No further work recommended \\
\hline 41 DV 22 & Prehistoric, Historic & No further work recommended \\
\hline 41 DV 23 & Prehistoric & No further work recommended \\
\hline $41 \mathrm{DV} 24$ & Prehistoric & Limited testing recommended \\
\hline $41 \mathrm{DV} 25$ & Prehistoric & No further work recommended \\
\hline $41 \mathrm{DV} 26$ & Prehistoric & Limited testing recommended \\
\hline 41 DV 27 & Prehistoric & Limited testing recommended \\
\hline 41 DV 28 & Prehistoric & No further work recommended \\
\hline 41 DV 29 & Prehistoric & No further work recommended \\
\hline 41 DV 30 & Prehistoric & No further work recommended \\
\hline 41 DV 31 & Prehistoric, Historic & No further work recommended \\
\hline $41 \mathrm{DV} 32$ & Prehistoric, Historic & No further work recommended \\
\hline 41 DV 33 & Prehistoric & No further work recommended \\
\hline $41 \mathrm{DV} 34$ & Prehistoric & No further work recommended \\
\hline 41 DV 35 & Historic & No further work recommended \\
\hline 41 DV 36 & Prehistoric & No further work recommended \\
\hline 41 DV 37 & Prehistoric & No further work recommended \\
\hline 41 DV 38 & Prehistoric & No further work recommended \\
\hline 41 DV 39 & Prehistoric & No further work recommended \\
\hline 41 DV 40 & Prehistoric & Limited testing recommended \\
\hline $41 \mathrm{DV} 41$ & Prehistoric & No further work recommended \\
\hline
\end{tabular}


The identification and discussion of the archaeological sites from Duval County represent a small glimpse into the prehistory and early historic development of this environmentally unique area. Man has productively exploited the varied natural resources of the brasada, or brush country, for countless centuries. This area of seemingly harsh natural conditions must be considered not only a significant, but an integral element in the study and understanding of south Texas archaeology.

\section{REFERENCES CITED}

Anderson, A. E.

1932 Artifacts of the Rio Grande Delta Region. Bulletin of the Texas Archeological and Paleontological Society 4:29-31.

Bailey, V.

1971 Mammals of the Southwestern United States. Dover Publications, New York.

Blair, W. F.

1950 The Biotic Provinces of Texas. The Texas Journal of Science 2(1):93-117.

Bolton, H. E.

1970 Texas in the Middle 18th Century. University of Texas Press, Austin and London. Published in cooperation with the Texas State Historical Association. Reprint of 1915 edition published as Vol. 3 of the University of California Publications in History.

Bryant, V. M., Jr.

1974 Prehistoric Diet in Southwest Texas: The Coprolite Evidence. American Antiquity 39:407-420.

Burt, W. H. and R. P. Grossenheider

1964 A Field Guide to the Mammals. Houghton Mifflin, Boston.

Campbell, T.N.

1947 The Johnson Site: Type Site of the Aransas Focus of the Texas Coast. Bulletin of the Texas Archeological and Paleontological Society 18:40-75.

1975 The Payaya Indians of Southern Texas. Southern Texas Archaeological Association, Special Publication 1. San Antonio.

Campbell, T. N. and T. J. Campbell

1981 Historic Indian Groups of the Choke Canyon Reservoir and Surrounding Areas, Southern Texas. Center for Archaeological Research, The University of Texas at San Antonio, Choke Canyon Series 1.

Cason, J. T.

1952 Report on Archeological Salvage in Falcon Reservoir: Season of $1952 . \quad$ Bulletin of the Texas Archeological Society 23:218-259. 


\section{References Cited}

Corbin, J. E.

1974 A Model for Cultural Succession for the Coastal Bend Area of Texas. Bulletin of the Texas Archeological Society 45:29-54.

Council of Texas Archeologists

1981 Guidelines for Curation Standards and Procedures. Council of Texas Archeologists, Newsletter 5(2).

Crabtree, D. E.

1972 An Introduction to Flintworking. Occasional Papers of the Idaho State University Museum 28, Pocatello, Idaho.

Dobie, J. F.

1929 A Vaquero of the Brush Country. Southwest Press, Dallas.

Epstein, J. F., T. R. Hester, and C. Graves

1980 Papers on the Prehistory of Northeastern Mexico and Adjacent Texas. Center for Archaeological Research, The University of Texas at San Antonio, Special Report 9.

Felger, R. S.

1977 Mesquite in Indian Cultures of Southwestern North America. In Mesquite: Its Biology in Two Desert Ecosystems, edited by B. B. Simpson:150-176. Dowden, Hutchinson, and Ross, Stroudsburg, Pennsylvania.

Flannery, K. V.

1968 Archaeological Systems Theory and Early Mesoamerica. In Anthropological Archaeology in the Americas, edited by B. J. Meggers:67-87. Anthropological Society of Washington, Washington, D.C.

Fox, A. A.

1977 An Archaeological Assessment of the San Antonio 201 Wastewater Treatment Project. Center for Archaeological Research, The University of Texas at San Antonio, Archaeological Survey Report 41.

Gerstle, A., T. C. Kelly, and C. Assad

1978 The Fort Sam Houston Project: An Archaeological and Historical Assessment. Center for Archaeological Research, The University of Texas at San Antonio, Archaeological Survey Report 40.

Gould, F. W.

1975 The Grasses of Texas. Texas A\&M University Press, College Station.

Hartle, D. D. and R. T. Stephenson

1951 Archeological Investigations at the Falcon Reservoir, Starr County, Texas. Mimeographed report on file, Texas Archeological Research Laboratory, Austin.

Hester, T. R.

1968 Paleo-Indian Artifacts from Sites Along San Miguel Creek: Frio, Atascosa, and McMullen Counties, Texas. Bulletin of the Texas Archeological Society 39:147-162. 
Hester, T. R. (continued)

1969a Archeological Investigations in Kenedy and Kleberg Counties, Texas, August, 1967. State Building Commission Archeological Program, Report 15, Austin.

1969b The Floyd Morris and Ayala Sites: A Discussion of Burial Practices in the Rio Grande Valley and the Lower Texas Coast. Bulletin of the Texas Archeological Society 40:147-166.

1971 The Surface Archeology of Three Sites in Duval County, Southern Texas. Lower Plains Archeological Society Bulletin 2:45-71.

1975a Chipped Stone Industries on the Rio Grande Plain, Texas: Some Preliminary Observations. The Texas Joumal of Science 26(1-2):213-222.

1975b A Chronological Overview of Prehistoric Southern and South-Central Texas. Paper presented at La Reunión Sobre Aspectos de Arqueología e Historia del Noreste, Monterrey, Nuevo León, Mexico.

1976 Hunters and Gatherers of the Rio Grande Plain and the Lower Coast of Texas. Center for Archaeological Research, The University of Texas at San Antonio.

1977 Archaeological Research at the Hinojosa Site (41 JW 8), Jim Wells County, Southern Texas. Center for Archaeological Research, The University of Texas at San Antonio, Archaeological Survey Report 42.

1980 Digging Into South Texas Prehistory. Corona Publishing Company, San Antonio.

1981 Tradition and Diversity Among the Prehistoric Hunters and Gatherers of Southern Texas. Plains Anthropologist 26(92):119-128.

Hester, T. R., R. F. Heizer, and J. A. Graham

1975 Field Methods in Archaeology. 6th edition. Mayfield Publishing Company, Palo Alto, California.

Hester, T. R. and T. C. Hill, Jr.

1971a An Initial Study of a Prehistoric Ceramic Tradition in Southern Texas. Plains Anthropologist 16(52):195-203.

1971b Notes on Scottsbluff Points from the Texas Coastal Plain. Southwestern Lore 37(1):27-38.

1975 Some Aspects of Late Prehistoric and Protohistoric Archaeology in Southern Texas. Center for Archaeological Research, The University of Texas at San Antonio, Special Report 1.

Hester, T. R. and R. C. Parker

1970 The Berclair Sites: A Late Prehistoric Component in Goliad County, Southern Texas. Bulletin of the Texas Archeological Society 41:1-24.

Hester, T. R. and H. J. Shafer

1975 An Initial Study of the Blade Technology on the Central and Southern Texas Coast. Plains Anthropologist 20(69):175-185. 


\section{References Cited}

Hester, T. R., L. O. White, and J. White

1969 Archeological Materials from the Oulline Site (41 LS 3) and Other Sites in LaSalle County, Texas. The Texas Joumal of Science 21(2):130-165.

Inglis, J. M.

1964 A History of Vegetation on the Rio Grande Plain. Texas Parks and Wildlife Department Bulletin 45.

Jackson, A. T.

1940 Tubular Pipes and Other Tubes in Texas. Bulletin of the Texas Archeological and Paleontological Society 12:99-137.

Jelks, E. B.

1952 The River Basin Surveys Archaeological Salvage Program in Texas. The Texas Joumal of Science 4(2):131-138.

1953 The River Basin Surveys: Recent Archaeological Investigations in Texas, Arkansas, and Kansas. The Texas Journal of Science 5(3):342-347.

Johnson, E. H.

1931 The Natural Regions of Texas. The University of Texas at Austin, Bureau of Business Research, Research Monograph 8.

Jones, T. B.

$1977 \quad$ Flora of the Texas Coastal Bend. Mission Press, Corpus Christi, Texas.

Kelley, J. C.

1947 The Cultural Affiliations and Chronological Position of the Clear Fork Focus. American Antiquity 13(2):97-109.

Lea, T.

1957 The King Ranch. Volumes I and III. Little, Brown and Company, Boston.

Lynn, W. M., D. E. Fox, and N. O’Malley

1977 Cultural Resource Survey of Choke Canyon Reservoir, Live Oak and McMullen Counties. Office of the State Archeologist, Texas Historical Commission, Archeological Survey Report 20.

MacNeish, R. S.

1947 A Preliminary Report on Coastal Tamaulipas. American Anthropologist 13(1):1-15.

1958 Preliminary Archaeological Investigations in the Sierra de Tamaulipas, Mexico, Transactions, American Philosophical Society 48(6).

Mallouf, R. J., B. J. Baskin, and K. L. Killen

1977 A Predictive Assessment of Cultural Resources in Hidalgo and Willacy Counties, Texas. Office of the State Archeologist, Texas Historical Commission, Archeological Survey Report 23. 
McClinton, K. M.

1951 Antique Collecting for Everyone. Bonanza Books, New York.

McGraw, A. J. and V. Kay Hindes

1987 Chipped Stone and Adobe: A Cultural Resources Assessment of the Proposed Applewhite Reservoir, Southwest Bexar County, Texas. Center for Archaeological Research, The University of Texas at San Antonio, Archaeological Survey Report 163.

Myres, S. L.

1969 The Ranch in Spanish-Texas: 1691-1800. Texas Western Press, The University of Texas at El Paso.

Nunley, J. P.

1971 Sociocultural Units of the Southwestern Archaic: An Analytic Approach. Ph.D. dissertation, Southern Methodist University, Dallas. University Microfilms, Ann Arbor.

Nunley, J. P. and T. R. Hester

1966 Preliminary Archeological Investigations in Dimmit County, Texas. The Texas Joumal of Science 18(3):233-253.

Peterson, H. L.

1962 The Treasury of the Gun. Golden Press, New York.

Peterson, R. T.

1963 A Field Guide to the Birds of Texas. Houghton Mifflin, Boston.

Prewitt, E. R. and T. A. Nance

1980 Archeological Survey and Assessments on the McBryde Lease, Duval County, Texas. Prewitt and Associates, Inc., Reports of Investigations 7, Austin.

Ramondino, S., editor

1968 The New World Spanish/English English/Spanish Dictionary. New American Library, New York.

Shafer, G. H.

1974 Ground-water Resources of Duval County, Texas. Texas Water Development Board Report 181.

Sibley, M. M.

1967 Travelers in Texas: 1761-1860. University of Texas Press, Austin.

Soil Conservation Service (SCS)

1980 Resource Concerns and Plan of Work. Agua Poquita Soil and Water Conservation District \#321, Benavides, Texas.

Stebbins, R. C.

1966 A Field Guide to Western Reptiles and Amphibians. Houghton Mifflin, Boston. 
Stiff, E.

1968 The Texian Emigrant: Being the Narration of the Adventures of the Author in Texas. Texian Press, Waco.

Story, D. A.

1980 Adaptive Strategies of Archaic Cultures of the West Gulf Coast Plain. Unpublished manuscript on file, Center for Archaeological Research, The University of Texas at San Antonio.

Suhm, D. A. and E. B. Jelks

1962 Handbook of Texas Archeology: Type Descriptions. Texas Archeological Society Special Publication 1 and Texas Memorial Museum Bulletin 4, Austin.

Suhm, D. A., A. D. Krieger, and E. B. Jelks

1954 An Introductory Handbook of Texas Archeology. Bulletin of the Texas Archeological Society 25.

Texas Historical Commission

1981 Guidelines for Archeological Investigations of Mining Areas in Texas. Office of the State Archeologist, Texas Historical Commission, Austin.

Texas Land Office

n.d. Archival Records. File Nos. S-229, S-231, 41135, 83745, and 83746. Austin, Texas.

U.S. Department of Agriculture

1981 General Soil Map: Duval County, Texas. Soil Conservation Service.

Webb, W. P. and H. B. Carroll

1952 The Handbook of Texas. Volumes 1 and 2. The Texas State Historical Association, Austin.

Weeks, A. W.

1933 Lissie, Reynosa, and Upland Terrace Deposits of Coastal Plain of Texas Between Brazos River and Rio Grande. Bulletin of the American Association of Petroleum Geologists 17(5):453-487.

Weir, F. A.

1956 Surface Artifacts from La Perdida, Starr County, Texas. Bulletin of the Texas Archeological Society 26:59-78.

Yellen, J. E.

1977 Archaeological Approaches to the Present. Academic Press, New York.

Zim, H. S. and H. M. Smith

1956 Reptiles and Amphibians. Golden Press, New York. 


\section{APPENDIX}

\section{DEFINITIONS OF LITHIC TERMS*}

Various terms common to lithic analyses are defined for this project since some variation, although slight, can be found among different sources. Comparisons with these definitions can be found in reports by Crabtree (1972:33-98) and Tixier (1974). For those interested, more detailed flake characteristics can be found in reports by Shafer (1973:83), Gunn and Mahula (1977:149), and $\operatorname{Katz}(1976)$.

ABRADING/GRINDING: Techniques used to alter the striking surface to a desired shape to receive optimum impact. Achieved by passing an abrasive material back and forth across the surface in a rubbing motion.

BEVEL: Removal of bits of flint from a surface to achieve a desired shape or angle.

BURNED CHERT: Any piece of debitage which exhibits characteristics associated with exposure to intense heat (e.g., potlids). If the piece of chert has flaking apparent on it, then it is included in the appropriate flake category.

CHIP: A piece of chert which exhibits some flake characteristics, but lacks a bulb of percussion, a platform, or both.

CHUNK: Distinguished from a chip by its thick, irregular, angular appearance. Exhibits no flake characteristics.

DISTAL END: The end of a flake which is opposite to the end bearing the bulb of percussion (proximal end).

DORSAL SURFACE: The side of the flake that is opposite the side which bears the bulb of percussion. On secondary or primary flakes, this would be the cortex-bearing side.

FLAKE: Distinguished from chips and chunks in that it possesses both a bulb of percussion and a striking platform.

HARD-HAMMER PERCUSSION: A reduction method which employs a hammerstone or similar material to apply force sufficient to detach a flake from the parent material.

LIP: An extended ridge or lip of the platform which overhangs the ventral side of the flake.

PLATFORM: The surface area of the proximal end which receives the force of impact during flake removal.

PLATFORM WIDTH: The dimension of the platform which is measured from one side of the flake to the other on an axis that is perpendicular to the axis extending from the dorsal face to the ventral face.

PRESSURE FLAKING: Removal of flakes by "pressing" a billet or similar tool to a desired location on the artifact and applying enough pressure to detach a flake.

PRIMARY FLAKE: A primary flake possesses cortex on $100 \%$ of the dorsal surface. Associated with the initial stages of lithic reduction.

PROXIMAL END: The end of the flake where the platform is located. Opposite the distal end.

SECONDARY FLAKE: A flake which exhibits 1 to $99 \%$ cortex on the dorsal surface and has evidence of one or more flake removals on the dorsal surface.

*Adapted from Black and McGraw (1985). 
SIDE: The outer edges of a flake when viewed with the dorsal or ventral surface toward the observer.

SOFT-HAMMER PERCUSSION: A reduction technique that is similar to the hard-hammer technique, but which utilizes a striking instrument considerably,softer such as bone, wood, or antler.

TERTIARY FLAKE: A flake which contains no cortex on any surface.

VENTRAL SURFACE: The inner surface of a flake upon which the bulb of percussion is located. Opposite the dorsal surface.

\section{REFERENCES CITED}

Black, S. L. and A. J. McGraw

1985 The Panther Springs Creek Site: Cultural Change and Continuity Within the Upper Salado Creek Watershed, South-Central Texas. Center for Archaeological Research, The University of Texas at San Antonio, Archaeological Survey Report 100.

Crabtree, D. E.

1972 An Introduction to Flintworking. Occasional Papers of the Idaho State University Museum 28, Pocatello, Idaho.

Gunn, J. and R. Mahula

1977 Hop Hill: Culture and Climatic Change in Central Texas. Center for Archaeological Research, The University of Texas at San Antonio, Special Report 5.

Katz, P. R.

1976 A Technological Analysis of the Kansas City Hopewell Chipped Stone Industry. Ph.D. dissertation, University of Kansas, Lawrence.

Shafer, H. J.

1973 Lithic Technology at the George C. Davis Site, Cherokee County, Texas. Ph.D.

Tixier, J. dissertation, Department of Anthropology, The University of Texas at Austin.

1974 Glossary for the Description of Stone Tools with Specific Reference to the Epipaleo-lithic of the Maghreb. M. H. Newcomer, translator. Newsletter of Lithic Technology, Special Publication 1, Washington State University, Pullman. 